\title{
Situasi, Kendala Dan Strategi Pengembangan Ekonomi Kreatif Kuliner Di Kabupaten Fakfak Provinsi Papua Barat
}

\author{
Els Tieneke Rieke Katmo ${ }^{1}$, Agus Sumule ${ }^{1}$, Ardha Puspitasari ${ }^{1}$, Diana Irbayanti ${ }^{1}$, Indra Irianti ${ }^{2}$, \\ Maria I Arim ${ }^{1}$ \\ ${ }^{1}$ Jurusan Sosial Ekonomi Pertanian Fakultas Pertanian Universitas Papua \\ ${ }^{2}$ Politeknik Pembangunan Pertanian Manokwari
}

Received: Februari 2020; Accepted: Maret 2020; Published: Maret 2020

\begin{abstract}
Abstrak
Kuliner adalah sektor ekonomi potensial di Kabupaten Fakfak dalam pertumbuhan ekonomi yang melambat. Dibandingkan dengan sektor Ekonomi Kreatif (EKRAF) lainnya, hasil pembobotan dengan analisis hirarki proses menunjukkan bahwa kuliner memiliki skor paling tinggi diantara sektor EKRAF lainnya. Hasil analisis SWOT menggambarkan bahwa berdasarkan penilaian terhadap kriteria-kriteria pada indicator -indikator dari dimensi sektor, proses dan actor, terdapat kekuatan, kelemahan, ancama dan peluang pada sektor Ekonomi Kreatif kuliner. Secara umum dari ketiga dimensi, sektor proses dan actor, indicator sumberdaya manusia menjadi kekuatan utama tetapi juga sekaligus merupakan kelemahan. Demikian pula halnya bahan baku sektor EKRAF kuliner. Kekuatan yang dimiliki adalah ketersediaan bahan baku secara memadai dan berkelanjutan baik kuantitas maupun kualitas terutama secara organik. Kekuatan dari elemen kelembagaan adalah adanya kebijakan nasional tentang EKRAF. Beberapa bahan baku terutama sektor kuliner dan kriya berasal dari sektor pertanian dan atau diambil dari alam tanpa melakukan tindakan budidaya. Kelemahan pada elemen bahan baku yang dipengaruhi oleh musim dan ancaman karena karakteristik produk pertanian. Dimensi proses pada kreasi dan distribusi sektor EKRAF kuliner juga masih lemah. Oleh sebab itu memperkuat proses produksi dengan memperbaiki beberapa aspek seperti teknologi dan infrastruktur pada proses kreasi sambil menjajaki peluangpeluang seperti perluasan pasar.
\end{abstract}

Kata kunci: ekonomi berkelanjutan, SWOT, ekonomi kreatif, kuliner

\section{Abstract}

Culinary is a potential creative economic sector in Fakfak in enhancing slow economic growth. In comparison to other creative economic sector, creative economic mapping in Fakfak indicated that culinary has highest scores. SWOT analysis that was applied to assess criterias of indicators from three dimentions which are sectors, process and actors indicated that human resources is the main strength but also weaknesses in culinary as well as raw material as resources that naturally provided. National Government policy regarding creative economic is strength in develops creatice economic in Fakfak. Yet, sustainability of culinary as potential creative economic sector depends on sustainability of natural resources and agriculture product. Threfore, increasing production process while improving the use of technology and infrastructure in creation is needed. This followed by market expansion.

Keywords: sustainable economic, SWOT, creative economic, culinary

How to Cite:Katmo, dkk (2020). Situasi, Kendala Dan Strategi Pengembangan Ekonomi Kreatif Kuliner Di Kabupaten Fakfak Provinsi Papua Barat. JFRES: Journal of Fiscal and Regional Economy Studies, 3(1), $34-49$

\footnotetext{
Corresponding author :

E-mail: els_katmo20@yahoo.com
} 


\section{PENDAHULUAN}

Ekonomi kreatif adalah aktivitas perekonomian berbasis kreatifitas yang mengacu pada kearifan lokal untuk mengelola bahan baku lokal sehingga melahirkan produk yang bernilai ekonomis. Sektor ekonomi kreatif meliputi arsitektur, desain interior, desain komunikasi visual, fotografi, kriya, kuliner, musik, fesyen, aplikasi dan game developer, penerbitan, periklanan, televisi dan radio, seni pertunjukan dan seni rupa. Data Listing Sensus Ekonomi (2016) di pulau Jawa menunjukkan bahwa kuliner merupakan sektor ekonomi kreatif unggulan kuliner $(67,66 \%)$. Berdasarkan hasil pemeringkatan ekonomi kreatif di Kabupaten Fakfak ditemukan bahwa sektor kuliner merupakan sektor potensial yang dapat mendorong pertumbuhan ekonomi Kabupaten Fakfak yang melambat dalam satu dekade belakangan ini. Mengacu pada kriteria penilaian pemeringkatan ekonomi kreatif dengan menggunakan Analisis Hirarki Proses (AHP), pembobotan terhadap sektor, aktor dan proses, sektor EKRAF kuliner merupakan sektor unggul. Hal ini didukung oleh ketersediaan Sumberdaya Manusia (SDM), bahan baku, industri, pembiayaan, akses pasar, infrastruktur, kelembagaan digunakan untuk melakukan penilaian terhadap kriteria sektor. Hasil AHP seperti terlihat pada Gambar 1 menggambarkan keunggulan sektor kuliner.

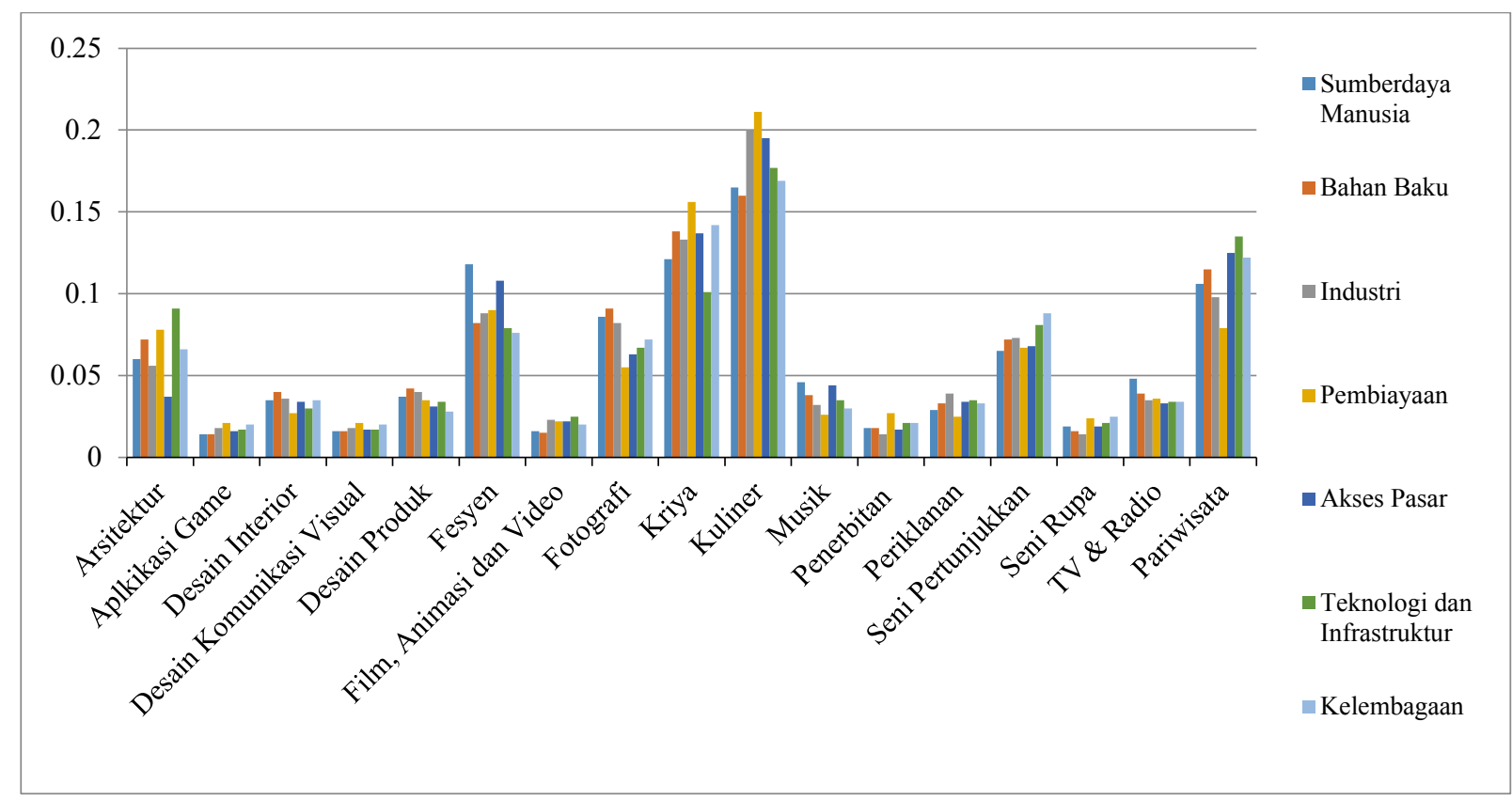

Sumber : Data Primer, 2018

Gambar 1. Hasil AHP Sektor Ekonomi Kreatif di Kabupaten Fakfak

Pemerintah, akademisi, komunitas dan pelaku bisnis, merupakan aspek yang digunakan untuk penilaian kriteria aktor. Hasil Analisis Hirarki Proses (AHP) yang digunakan dalam melakukan pemeringkatan ekonomi kreatif di Kabupaten Fakfak menunjukkan bahwa sektor kuliner pada dimensi aktor memiliki nilai tertinggi. Pembobotan dimensi proses dengan menggunakan AHP untuk menilai kriteria kreasi, distribusi, dan konsumsi juga menunjukkan bahwa sektor kuliner memiliki bobot yang tinggi.

Walaupun memiliki nilai tertinggi berdasarkan hasil pembobotan, untuk menjaga keberlanjutan sektor kuliner sebagai sektor unggulan maka perlu dikembangan strategi yang mendukung keberlanjutan sektor ekonomi kreatif ini. Basis bahan baku yang digunakan pada sektor kuliner di Kabupaten Fakfak adalah pertanian dan perikanan. Hal ini didukung oleh ketersediaan sumberdaya alam yang melimpah di Kabupaten Fakfak. Olahan pala, durian dan perikanan mendominasi sektor ekonomi kreatif kuliner di Kabupaten Fakfak karena selain ketersediaan bahan baku yang cukup, sektor kuliner memiliki nilai budaya dan historis yang panjang bagi masyarakat Fakfak.Tetapi sebagai produk pertanian, bahan baku utama dari sektor kuliner tentu sangat dipengaruhi oleh sifat-sifat produk pertanian dan iklim yang membutuhkan penanganan yang baik sehingga kontinuitas 
produksi terus terjaga. Seperti telah dikemukakan di atas bahwa ekonomi kreatif adalah aktivitas ekonomi yang mengandalkan kreatifitas sumberdaya manusia selain berbasis ilmu pengetahuan dan merupakan warisan budaya dan teknologi (Badan Ekonomi Kreatif Nasional, 2016). Tulisan ini mengkaji strategi pengembangan sektor kuliner berdasarkan hasil analisis SWOT untuk memahami kekuatan, kelemahan, peluang dan hambatan yang ada pada pengembangan ekonomi kreatif kuliner.

\section{METODE PENELITIAN}

Tulisan ini merupakan abstraksi dari hasil penelitian yang dilakukan di Distrik Arguni, Distrik Kokas, Distrik Kramomongga dan Kota Fakfak selama bulan Oktober tahun 2018. Wawancara, pengamatan (observasi), studi pustaka (literature) dan diskusi kelompok terfokus (FGD) adalah teknik pengumpulan data yang digunakan di dalam penelitian ini. Sejumlah partisipan yang terlibat di dalam penelitian ini terdiri dari akademisi, pelaku bisnis, kreator, komunitas, pemerintah daerah, tokoh adat, dan beberapa informan kunci terkait dengan pengembangan ekonomi kreatif. Daftar isu atau topik dan sejumlah pertanyaan terstruktur di dalam kuisioner digunakan sebagai panduan pengumpulan data. Data-data tersebut kemudian dianalisis dengan menggunakan menggunakan SWOT untuk mengetahui kendala, hambatan dan strategi pengembangan ekonomi kreatif daerah. Setelah ditemukan skor terbaik dari sektor-sektor ekonomi kreatif, dilakukan penetapan strategi pengembangan dengan menggunakan matriks TOWS. Instrument penelitian ini dikembangkan untuk mengkaji empat elemen ekonomi kreatif potensial berdasarkan hasil pemeringkatan dengan menggunakan AHP.

Indikator-indikator kekuatan, kelemahan, peluang, ancaman dari pengembangan potensi ekonomi kreatif diformulasi untuk menilai kondisi saat ini dan urgensi penanganannya pada setiap elemen ekonomi kreatif. Penilaian kondisi saat ini dibagi dalam empat kategori yang terdiri dari ada dan banyak (3), ada dan sedikit (2), tidak ada tetapi bisa dikembangkan (1), dan tidak bisa dan tidak dapat dikembangkan (0) dan penialian urgensi penanganan dijabarkan dalam empat kategori yakni tidak urgen (1), kurang urgen (2), urgen (3) dan sangat urgen (4). Secara rinci kategorisasi tersebut adalah sebagai berikut:
Penilaian kondisi saat ini (rating):

Angka $0=$ tidak ada dan tidak bisa dikembangkan

Angka 1 = tidak ada tetapi bisa dikembangkan

Angka 2 = ada dan sedikit

Angka 3 = ada dan banyak

Penilaian urgensi penanganan (integrity):

Angka $1=$ tidak urgen

Angka $2=$ kurang urgen

Angka $3=$ urgen

Angka 4 = sangat urgen

Indikator dalam analisis SWOT menurut setiap elemen ekonomi kreatif akan dikembangkan pada potensi pengembangan ekonomi kreatif daerah. Variabel yang dapat dipakai dalam melakukan penilaian terhadap suatu keadaan atau kemungkinan dilakukan pengukuran terhadap perubahan-perubahan yang terjadi dari waktu ke waktu. Indikator tidak selalu menjelaskan keadaaan keseluruhan tetapi seringkali menjadi indikasi keadaan keseluruhan sebagai penduga. Indikator-indikator tersebut mencakup kekuatan, kelemahan, peluang dan ancaman yang dikembangkan dari data yang dikumpulkan untuk dimensi elemen sektor ekonomi kreatif. Dimensi merupakan faktor yang menjadi ukuran berfungsinya suatu elemen (Badan Ekonomi Kreatif, 2016). Sedangkan elemen adalah indikator pemeringkatan yang diperlukan unutk bergerak secara sistemik sebagai entatitas kreatif baik berskala lokal, regional, nasional maupun global (Badan Ekonomi Kreatif, 2016).

Formulasi strategis untuk pengembangan ekonomi kreatif daerah disusun dengan menggunakan hasil analisis SWOT dengan cara menggabungkan indikator-indikator yang terdapat dalam kekuatan, kelemahan, peluang dan ancaman. Indikator-indikator dalam analisis SWOT kemudian digunakan untuk menilai elemen-elemen ekonomi kreatif. Model penggabunganya akan menggunakan TOWS matriks. TOWS matriks menggambarkan pilihan-pilihan strategi untuk memecahkan isu dalam pengembangan ekonomi kreatif daerah dengan mengawinkan kekuatan dengan peluang (SO strategy), kekuatan dengan ancaman (ST stretegy), kelemahan dengan peluang (WO strategy) dan kelemahan dengan ancaman (WO 
strategy), (Rangkuti, 2012). Secara skematik TOWS matriks digambarkan seperti pada Tabel 1. Rangkuti (2012) menjelaskan strategi pada tiap-tiap kuadran adalah sebagai berikut: SOstrategy adalah strategi yang disusun dengan cara menggunakan semua kekuatan untuk merebut peluang. W-O strategy adalah yang disusun dengan cara meminimalkan kelemahan untuk memanfaatkan peluang yang ada. S-T strategy adalah strategi yang disusun dengan cara menggunakan semua kekuatan untuk mengatasi ancaman. W-T strategy adalah strategi yang disusun dengan cara meminimalkan kelemahan untuk menghindari ancaman.

Tabel 1. Matriks TOWS

\begin{tabular}{|c|c|c|c|}
\hline \multirow{4}{*}{ 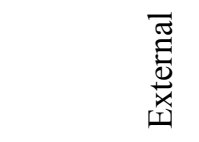 } & \multicolumn{3}{|c|}{ Internal } \\
\hline & & Strength & Weaknesses \\
\hline & Opportunity & SO Strategy & WO Strategy \\
\hline & Threaths & ST Strategy & WT Strategy \\
\hline
\end{tabular}

Sumber : Rangkuti, 2012

\section{HASIL DAN PEMBAHASAN}

Analisis SWOT digunakan dengan membandingkan faktor Eksternal (peluang dan ancaman) dengan faktor internal (kekuatan dan kelemahan). Analisis SWOT terhadap sektor kuliner sebagai sektor potensial ekonomi kreatif di Kabupaten Fakfak mencakup dimensi sektor, dimensi aktor dan dimensi proses. Pada masingmasing indikator diberi nilai sesuai kategori untuk menghitung skor dari integrity dan rating dari ketiga dimensi pada sektor kuliner.

\section{Dimensi Sektor}

\section{Hasil Analisisi SWOT Dimensi Sektor Ekonomi Kreatif Kuliner}

Pada dimensi sektor terdapat tujuh indikator yang dinilai berdasarkan kriteria dari setiap indikator. Penilaian terhadap kondisi saat (rating) dan urgensi penangan (integrity) akan membentuk skor yang penjumlahannya digunakan untuk menentukan strategi-strategi berdasarkan kuadran pada analisis SWOT. Tujuh indikator tersebut yakni sumberdaya manusia, bahan baku, industri, pembiayaan, akses pemasaran produk dan potensi, infrastruktur dan teknologi serta kelembagaan, yang akan dipilah ke dalam kriteria-kriteria yang kemudian dinilai kekuatan dan kelemahannya.

Sektor kuliner memiliki kekuatan yang besar (156) berdasarkan perhitungan skor integrity dan rating. Walaupun demikian terdapat beberapa kelemahan yaitu pada indikator SDM belum ada perlindungan kerja bagi SDM yang berkeja pada sektor kuliner. Hal ini disebabkan oleh karena skala usaha kuliner masih kecil sampai menengah. Pada indikator industri terdapat kelemahan pada diversifikasi produk yakni belum ada variasi olahan dalam bentuk lain terutama appetizer dan dissert. Kelemahan pada akses pemasaran dan potensi pemasaran serta promosi menunjukkan bahwa belum ada perluasan pasar ke tingkat nasional dan internasional, masih terkonsektrasi pada pasar lokal. Beberapa kegiatan promosi ke tingkat nasional telah dilakukan tetapi tidak dilakukan secara reguler dan masih bersifat sporadis. Kelemahan terbesar dari sektor kuliner adalah pada indikator kelembagaan yang meliputi belum adanya regulasi yang mendukung EKRAF di tingkat daerah, dan kurangnya apresiasi bagi pelaku bisnis kuliner dan partisipasi pada festival baik di tingkat lokal, nasional dan internasional. Secara rinci pembobotan kekuatan dan kelemahan pada dimensi sektor kuliner dapat dilihat pada Tabel 2. Penilaian terhadap peluang dan ancaman dari ketujuh indikator berikut kriteria-kriterianya digunakan untuk menilai sektor EKRAF kuliner. Berdasarkan hasil pembobotan total skor peluang lebih besar (72) dibandingkan dengan ancaman (60) seperti terlihat pada Tabel 3. Secara rinci ancaman yang ditemui di dalam ekonomi kreatif kuliner adalah pada sumberdaya manusia yaitu pemekaran wilayah menyebabkan orang cenderung bekerja sebagai PNS pada wilayah-wilayah pemekaran baru. Ancaman lainnya adalah bahan baku yang digunakan dengan total skor yang besar. Hal ini disebabkan karena sebagian besar bahan baku adalah produk pertanian. Selain itu kepercayaan pemberi modal usaha kepada pengusaha adalah ancaman lainnya yang dihadapi sektor EKRAF kuliner. Akses pasar dan perluasan pasar, infrastruktur dan teknologi serta kelembagaan merupakan peluang dengan skor yang tinggi. Teknologi kemasan dan labeling pada produk olahan kuliner menjadi peluang tetapi ratingya rendah karena dalam kenyataannya kemasan dan labeling tidak diproduksi di Fakfak tetapi didatangkan dari luar (Jawa). 
Tabel 2. Pembobotan Kekuatan dan Kelemahan Dimensi Sektor Kuliner

\begin{tabular}{|c|c|c|c|c|c|c|c|}
\hline \multirow{2}{*}{ Indikator } & \multirow{2}{*}{ Kriteria } & \multicolumn{3}{|c|}{ Kekuatan } & \multicolumn{3}{|c|}{ Kelemahan } \\
\hline & & Integrity & Rating & Skor & Integrity & Rating & Skor \\
\hline \multirow{3}{*}{$\begin{array}{l}\text { Sumberdaya } \\
\text { Manusia }\end{array}$} & $\begin{array}{l}\text { Tingkat kompetensi aktor yang bekerja pada sub-sektor } \\
\text { kuliner (misalya chef/Koki) }\end{array}$ & 4 & 2 & 8 & & & \\
\hline & $\begin{array}{l}\text { Lembaga pendidikan yang mencetak aktor yang bekerja pada } \\
\text { sub-sektor kuliner }\end{array}$ & 4 & 2 & 8 & & & \\
\hline & Memiliki perlindungan tenaga kerja & & & & 4 & 0 & 0 \\
\hline \multirow{3}{*}{ Bahan baku } & $\begin{array}{l}\text { Bahan baku yang digunakan diperoleh dengan cara budidaya } \\
\text { organik }\end{array}$ & 4 & 3 & 12 & & & \\
\hline & $\begin{array}{l}\text { Bahan baku yang digunakan diperoleh dengan cara budidaya } \\
\text { an-organik }\end{array}$ & 4 & 2 & 8 & & & \\
\hline & Standarisasi higenitas dimiliki oleh produk kuliner unggulan & 4 & 2 & 8 & & & \\
\hline \multirow{7}{*}{ Industri } & Jenis produk yang dihasilkan berupa Appetizer & & & & 4 & 1 & 4 \\
\hline & Jenis produk yang dihasilkan berupa main course & 4 & 2 & 8 & & & \\
\hline & Jenis produk yang dihasilkan berupa Dissert & & & & 4 & 1 & 4 \\
\hline & Jenis produk yang dihasilkan berupa snack & 4 & 2 & 8 & & & \\
\hline & Jenis produk yang dihasilkan berupa beverage & 4 & 3 & 12 & & & \\
\hline & Jumlah usaha kuliner formal & 4 & 2 & 8 & & & \\
\hline & Jumlah usaha kuliner non-formal & 4 & 3 & 12 & & & \\
\hline Pembiayaan & $\begin{array}{l}\text { Ada sumber dana yang digunakan untuk pembiayaan } \\
\text { kegiatan industri ini }\end{array}$ & 4 & 2 & 8 & & & \\
\hline \multirow{6}{*}{$\begin{array}{l}\text { Akses } \\
\text { pemasaran } \\
\text { produk dan } \\
\text { potensi }\end{array}$} & Pasar lokal & 4 & 3 & 12 & & & \\
\hline & Pasar nasional & & & & 4 & 1 & 4 \\
\hline & Pengembangan pemasaran ke pasar internasional & & & & 4 & 0 & 0 \\
\hline & $\begin{array}{l}\text { Kegiatan mempromosikan dan menjual produk kuliner } \\
\text { secara lokal }\end{array}$ & 4 & 3 & 12 & & & \\
\hline & $\begin{array}{l}\text { Kegiatan mempromosikan dan menjual produk kuliner ke } \\
\text { tingkat nasional }\end{array}$ & & & & 4 & 1 & 4 \\
\hline & $\begin{array}{l}\text { Kegiatan mempromosikan dan menjual produk kuliner ke } \\
\text { tingkat internasional }\end{array}$ & & & & 4 & 0 & 0 \\
\hline \multirow{4}{*}{$\begin{array}{l}\text { Infrastruktur dan } \\
\text { teknologi yang } \\
\text { mendukung sub- } \\
\text { sektor kuliner }\end{array}$} & Infrastruktur logistik dan energi & & & & 4 & 1 & 4 \\
\hline & Infrastruktur komunikasi & 4 & 2 & 8 & & & \\
\hline & Infrastuktur pasar & 4 & 3 & 12 & & & \\
\hline & Infrastruktur jalan raya & 4 & 3 & 12 & & & \\
\hline \multirow{5}{*}{ Kelembagaan } & Ada regulasi yang mendukung EKRAF & & & & 4 & 1 & 4 \\
\hline & $\begin{array}{l}\text { Aspek apresiasi: Penghargaan pelaku bisnis yang terlibat } \\
\text { dalam usaha kreatif kuliner di tingkat lokal, nasional dan } \\
\text { internasional }\end{array}$ & & & & 4 & 1 & 4 \\
\hline & Partisipasi dari sub-sektor ini di festival atau acara nasional & & & & 4 & 1 & 4 \\
\hline & $\begin{array}{l}\text { Partisipasi dari sub-sektor ini di festival atau acara } \\
\text { internasional }\end{array}$ & & & & 4 & 1 & 4 \\
\hline & Total & & & 156 & & & 36 \\
\hline
\end{tabular}

Sumber: Data Primer, 2018

\section{Tabel 3. Pembobotan Peluang dan Ancaman Dimensi Sektor}

\begin{tabular}{|c|c|c|c|c|c|c|c|}
\hline \multirow{2}{*}{ Indikator } & \multirow{2}{*}{ Kriteria } & \multicolumn{3}{|c|}{ Peluang } & \multicolumn{3}{|c|}{ Ancaman } \\
\hline & & Integrity & Rating & Skor & Integrity & Rating & Skor \\
\hline \multirow[t]{2}{*}{$\begin{array}{l}\text { Sumberdaya } \\
\text { Manusia }\end{array}$} & $\begin{array}{l}\text { Ada pelatihan untuk pengolahan hasil (pala, durian, sagu, } \\
\text { ikan) bagi anggota kelompok usaha }\end{array}$ & 4 & 3 & 12 & & & \\
\hline & $\begin{array}{l}\text { Pemekaran wilayah mendorong orang untuk beralih menjadi } \\
\text { PNS }\end{array}$ & & & & 4 & 3 & 12 \\
\hline \multirow{8}{*}{$\begin{array}{l}\text { Bahan baku } \\
\text { fisik }\end{array}$} & Serangan Hama Penyakit terhadap tanaman & & & & 4 & 3 & 12 \\
\hline & Cuaca yang tidak bisa diprediksi & & & & 4 & 0 & 0 \\
\hline & $\begin{array}{l}\text { Gangguan lingkungan terhadap produksi bahan baku } \\
\text { (misalnya pertumbuhan rumput laut yang terganggu oleh } \\
\text { usaha perahu viber) }\end{array}$ & & & & 4 & 1 & 4 \\
\hline & Topografi yang sulit untuk pengangkutan & & & & 4 & 0 & 0 \\
\hline & $\begin{array}{l}\text { Harga bunga pala dan biji yang tinggi mendorong orang } \\
\text { untuk beralih pada bisnis bunga dan pala }\end{array}$ & & & & 4 & 3 & 12 \\
\hline & $\begin{array}{l}\text { Permintaan dari bahan mentah (ikan) yang tinggi untuk } \\
\text { eksport }\end{array}$ & & & & 4 & 3 & 12 \\
\hline & Masalah kontinuitas produksi karena musiman & & & & 4 & 0 & 0 \\
\hline & $\begin{array}{l}\text { Ada program Pemerintah untuk diversivikasi olahan } \\
\text { misalnya sagu }\end{array}$ & 4 & 2 & 8 & & & \\
\hline \multirow[t]{2}{*}{ Pembiayaan } & $\begin{array}{l}\text { Ada bantuan modal usaha dari perusahaan dan lembaga } \\
\text { keuangan }\end{array}$ & 3 & 1 & 3 & & & \\
\hline & Trust dari pemberi modal & & & & 4 & 2 & 8 \\
\hline \multirow{3}{*}{$\begin{array}{l}\text { Akses dan } \\
\text { perluasan pasar }\end{array}$} & Selera konsumen dan gaya hidup sehat (healthy life trend) & 3 & 2 & 6 & & & \\
\hline & Pala sebagai ole-ole khas Fakfak & 4 & 3 & 12 & & & \\
\hline & Pemasaran secara online menjadi trend saat ini & 3 & 1 & 3 & & & \\
\hline \multirow{3}{*}{$\begin{array}{l}\text { Infrastruktur } \\
\text { dan teknologi } \\
\text { yang } \\
\text { mendukung } \\
\text { sub-sektor } \\
\text { kuliner }\end{array}$} & Koneksi internet kurang kuat & 4 & 2 & 8 & & & \\
\hline & Listrik yang sering padam & 4 & 3 & 12 & & & \\
\hline & Teknologi kemasan dan labeling dihasilkan diluar Fakfak & 4 & 0 & 0 & & & \\
\hline \multirow[t]{2}{*}{ Kelembagaan } & Ada kebijakan pangan lokal & 4 & 2 & 8 & & & \\
\hline & Total & & & 72 & & & 60 \\
\hline
\end{tabular}




\section{Dimensi Proses}

\section{Hasil Analisis SWOT Pada Dimensi Proses Sektor EKRAF Kuliner}

\section{Indikator Kreasi}

Dimensi proses meliputi tiga indikator yakni kreasi, produksi dan distribusi. Dimensi proses pada indikator kreasi terdiri dari sumberdaya manusia, pembiayaan dan Jejaring (network). Secara rinci berdasarkan hasil pembobotan kekuatan dan kelemahan pada indikator kreasi (Tabel 4) terlihat bahwa SDM dan pembiayaan menjadi kekuatan (skor 16) pada indikator kreasi dan jejaring (skor 8) menjadi kelemahan.
Pembobotan peluang dan ancaman pada indikator kreasi meliputi SDM, pengetahuan, teknologi, ketrampilan, pembiayaan, dan jejaring. Secara terperinci pembobotan peluang dan ancaman pada indikator kreasi (Tabel 5) mengindikasikan bahwa pada indikator kreasi skor ancaman lebih besar dibandingkan peluang. Skor peluang terbesar hanya pada pada ketrampilan. Artinya ketrampilan kuliner yang dimiliki pelaku bisnis kuliner menjadi peluang walaupun terdapat ancaman pada indikatorindikator lainnya. Ancaman terbesar datang indikator kreasi lainnya; SDM, pengetahuan, teknologi, pembiayaan dan jejaring.

Tabel 4. Pembobotan Kekuatan dan Kelemahan Pada Indikator Kreasi

\begin{tabular}{|c|c|c|c|c|c|c|c|}
\hline \multirow[t]{2}{*}{ Indikator Kreasi } & \multirow[t]{2}{*}{ Kriteria } & \multicolumn{3}{|c|}{ Kekuatan } & \multicolumn{3}{|c|}{ Kelemahan } \\
\hline & & Integrity & Rating & Skor & Integrity & Rating & Skor \\
\hline $\begin{array}{l}\text { Sumberdaya } \\
\text { Manusia }\end{array}$ & Sumbedaya manusia yang menciptakan kreasi & 4 & 2 & 8 & & & \\
\hline Pembiayaan & $\begin{array}{l}\text { Ketersediaan lembaga keuangan yang mendukung tahap } \\
\text { kreasi seperti perbankan }\end{array}$ & 4 & 2 & 8 & & & \\
\hline \multirow{4}{*}{ Jejaring/Network } & $\begin{array}{l}\text { Ketersediaan jejaring untuk mendukung tahap kreasi di } \\
\text { tingkat lokal }\end{array}$ & & & & 4 & 1 & 4 \\
\hline & $\begin{array}{l}\text { Ketersediaan jejaring untuk mendukung tahap kreasi di } \\
\text { tingkat nasional }\end{array}$ & & & & 4 & 1 & 4 \\
\hline & $\begin{array}{l}\text { Ketersediaan jejaring untuk mendukung tahap kreasi di } \\
\text { tingkat internasional }\end{array}$ & & & & 4 & 0 & 0 \\
\hline & \begin{tabular}{|c|} 
Total Skor \\
\end{tabular} & & & 16 & & & 8 \\
\hline
\end{tabular}

Sumber: Data Primer, 2019

Tabel 5 Pembobotan Peluang dan Ancaman pada Indikator Kreasi

\begin{tabular}{|c|c|c|c|c|c|c|c|}
\hline \multirow{2}{*}{ Indikator Kreasi } & \multirow{2}{*}{ Kriteria } & \multicolumn{3}{|c|}{ Peluang } & \multicolumn{3}{|c|}{ Ancaman } \\
\hline & & Integrity & Rating & Skor & Integrity & Rating & Skor \\
\hline \multirow[t]{2}{*}{$\begin{array}{l}\text { Sumberdaya } \\
\text { Manusia }\end{array}$} & $\begin{array}{l}\text { Pemekaran wilayah menyerap banyak lulusan termasuk } \\
\text { lulusan sekolah vokasi }\end{array}$ & & & & 4 & 3 & 12 \\
\hline & $\begin{array}{l}\text { Lembaga pendidikan yang mendorong penciptaan kreator } \\
\text { di sub-sektor kuliner (Sekolah vokasi) }\end{array}$ & & & & 4 & 1 & 4 \\
\hline \multirow[t]{2}{*}{ Pengetahuan } & $\begin{array}{l}\text { Tersedia literatur, dokument atau data yang mendorong } \\
\text { munculnya kreator di sub-sektor kuliner }\end{array}$ & & & & 4 & 0 & 0 \\
\hline & $\begin{array}{l}\text { Ketersediaan prasarana yang mendukung para kreator } \\
\text { untuk mendapatkan inspirasi dalam berkarya; } \\
\text { perpustakaan, lembaga pendidikan }\end{array}$ & & & & 4 & 0 & 0 \\
\hline Teknologi & $\begin{array}{l}\text { Ketersediaan teknologi khusus yang digunakan dalam } \\
\text { tahap kreasi }\end{array}$ & & & & 4 & 0 & 0 \\
\hline \multirow[t]{2}{*}{ Ketrampilan } & $\begin{array}{l}\text { Ketersediaan ketrampilan khusus pada tahap kreasi } \\
\text { (ketrampilan berijazah) }\end{array}$ & & & & 4 & 1 & 4 \\
\hline & $\begin{array}{l}\text { Ketersediaan pelatihan, workshop, kursus, lembaga } \\
\text { pendidikan formal/informal pada tahap kreasi }\end{array}$ & 4 & 2 & 8 & & & \\
\hline Pembiayaan & Trust dari lembaga keuangan & & & & 4 & 2 & 8 \\
\hline \multirow[t]{3}{*}{ Jejaring/Network } & $\begin{array}{l}\text { Jejaring yang terbentuk untuk mendukung tahap kreasi di } \\
\text { tingkat lokal tidak di kontrol oleh pengusaha itu sendiri }\end{array}$ & & & & 4 & 0 & 0 \\
\hline & $\begin{array}{l}\text { Ketersediaan jejaring untuk mendukung tahap kreasi di } \\
\text { tingkat nasional }\end{array}$ & & & & 4 & 1 & 4 \\
\hline & $\begin{array}{l}\text { Ketersediaan jejaring untuk mendukung tahap kreasi di } \\
\text { tingkat internasional }\end{array}$ & & & & 4 & 0 & 0 \\
\hline \multicolumn{2}{|r|}{ Total Skor } & & & 8 & & & 32 \\
\hline
\end{tabular}

Sumber: Data Primer, 2019

\section{Indikator Produksi}

Produksi merupakan kegiatan utama dalam sektor kuliner. Terdapat beberapa indikator produksi yaitu SDM, bahan baku, standart, sertifikasi dan pengendalian mutu, teknologi dan pengelolaan, infrastruktur, pembiayaan, jejaring, dan pergudangan. Hasil pembobotan kekuatan dan kelemahan pada indikator produksi (Tabel
6) menunjukkan bahwa bahan baku, infrastruktur, teknologi dan pengelolaan, pembiayaan dan jejaring memiliki menjadi kekuatan pada indikator produksi dengan skor tinggi (108). Sumberdaya manusia, standard dan sertifikasi serta pengendalian mutu dan pergudangan merupakan kelemahan di dalam produksi kuliner dengan skor 56 (Tabel 7). 
Tabel 6. Pembobotan Kekuatan dan Kelemahan pada Indikator Produksi

\begin{tabular}{|c|c|c|c|c|c|c|c|}
\hline \multirow{2}{*}{$\begin{array}{l}\text { Indikator } \\
\text { Produksi }\end{array}$} & \multirow[t]{2}{*}{ Kriteria } & \multicolumn{3}{|c|}{ Kekuatan } & \multicolumn{3}{|c|}{ Kelemahan } \\
\hline & & Integrity & Rating & Skor & Integrity & Rating & Skor \\
\hline \multirow{4}{*}{$\begin{array}{l}\text { Sumberdaya } \\
\text { Manusia }\end{array}$} & Ketersediaan pekerja pada tahap produksi & & & & 4 & 1 & 4 \\
\hline & Ketersediaan tenaga pengawas & & & & 4 & 1 & 4 \\
\hline & Ketersediaan manager & & & & 4 & 1 & 4 \\
\hline & Ketersediaan tenaga ahli professional & & & & 4 & 0 & 0 \\
\hline \multirow[t]{6}{*}{ Bahan Baku } & Ketersediaan bahan baku dalam kuantitas yang cukup & 4 & 3 & 12 & & & \\
\hline & Ketersediaan bahan baku dalam kualitas yang cukup & 4 & 2 & 8 & & & \\
\hline & Ketersediaan bahan baku dengan harga terjangkau & 4 & 3 & 12 & & & \\
\hline & Akses pemenuhan kebutuhan & 4 & 2 & 8 & & & \\
\hline & Pola pemanfaatan bahan baku & 4 & 2 & 8 & & & \\
\hline & Penyimpanan & & & & 4 & 1 & 4 \\
\hline \multirow{2}{*}{$\begin{array}{l}\text { Standard \& } \\
\text { Sertifikasi serta } \\
\text { pengendalian } \\
\text { mutu }\end{array}$} & $\begin{array}{l}\text { Ketersediaan standardisasi dan sertifikat pada tahap } \\
\text { produksi }\end{array}$ & & & & 4 & 1 & 4 \\
\hline & $\begin{array}{l}\text { Ketersediaan pengendalian mutu bahan baku, konten, } \\
\text { kemasan pada tahap produksi }\end{array}$ & & & & 4 & 1 & 4 \\
\hline \multirow[t]{5}{*}{$\begin{array}{l}\text { Teknologi dan } \\
\text { Pengelolaan }\end{array}$} & $\begin{array}{l}\text { Ketersediaan teknologi untuk mendukung tahap produksi } \\
\text { (i.e. mesin) }\end{array}$ & 4 & 2 & 8 & & & \\
\hline & Ketersediaan pengelolaan produksi & & & & 4 & 1 & 4 \\
\hline & Ketersediaan pengelolaan kualitas produk & & & & 4 & 1 & 4 \\
\hline & Ketersediaan pengelolaan pengemasan & & & & 4 & 1 & 4 \\
\hline & Ketersediaan pengelolaan penyimpanan & & & & 4 & 1 & 4 \\
\hline \multirow[t]{5}{*}{ Infrastruktur } & Ketersediaan prasarana yang jalan raya & 4 & 3 & 12 & & & \\
\hline & Ketersediaan prasarana yang listrik & 4 & 2 & 8 & & & \\
\hline & Ketersediaan prasarana internet & & & & 4 & 1 & 4 \\
\hline & Ketersediaan frekuensi radio/televisi & 4 & 2 & 8 & & & \\
\hline & Ketersediaan Jejaring telepon & 4 & 2 & 8 & & & \\
\hline Pembiayaan & $\begin{array}{l}\text { Ketersediaan lembaga keuangan yang mendukung tahap } \\
\text { produksi }\end{array}$ & 4 & 2 & 8 & & & \\
\hline \multirow[t]{3}{*}{ Jejaring } & $\begin{array}{l}\text { Ketersediaan jejaring untuk mendukung tahap kreasi di } \\
\text { tingkat lokal }\end{array}$ & 4 & 2 & 8 & & & \\
\hline & $\begin{array}{l}\text { Ketersediaan jejaring untuk mendukung tahap kreasi di } \\
\text { tingkat nasional }\end{array}$ & & & & 4 & 1 & 4 \\
\hline & $\begin{array}{l}\text { Ketersediaan jejaring untuk mendukung tahap kreasi di } \\
\text { tingkat internasional }\end{array}$ & & & & 4 & 0 & 0 \\
\hline \multirow{2}{*}{ Pergudangan } & Ketersediaan sarana penyimpanan; gudang & & & & 4 & 1 & 4 \\
\hline & Ketersediaan sarana penyimpanan; strorage & & & & 4 & 1 & 4 \\
\hline & Total & & & 108 & & & 56 \\
\hline
\end{tabular}

Sumber: Data Primer, 2019

Tabel 7. Pembobotan Peluang dan Ancaman pada Indikator Produksi

\begin{tabular}{|c|c|c|c|c|c|c|c|}
\hline \multirow{2}{*}{$\begin{array}{l}\text { Indikator } \\
\text { Produksi }\end{array}$} & \multirow{2}{*}{ Kriteria } & \multicolumn{3}{|c|}{ Peluang } & \multicolumn{3}{|c|}{ Ancaman } \\
\hline & & Integrity & Rating & Skor & Integrity & Rating & Skor \\
\hline $\begin{array}{l}\text { Sumberdaya } \\
\text { Manusia }\end{array}$ & Pemekaran wilayah menyerap banyak tenaga kerja & & & & 3 & 3 & 9 \\
\hline \multirow[t]{9}{*}{ Bahan Baku } & Serangan Hama Penyakit terhadap tanaman & & & & 3 & 2 & 6 \\
\hline & Cuaca yang tidak bisa kontrol & & & & 4 & 0 & 0 \\
\hline & Perubahan iklim & & & & 4 & 0 & 0 \\
\hline & $\begin{array}{l}\text { Gangguan lingkungan terhadap produksi bahan baku } \\
\text { (misalnya pertumbuhan rumput laut yang terganggu oleh } \\
\text { usaha perahu viber) }\end{array}$ & & & & 4 & 1 & 4 \\
\hline & Topografi yang sulit untuk pengangkutan & & & & 4 & 3 & 12 \\
\hline & $\begin{array}{l}\text { Harga bunga pala dan biji yang tinggi mendorong orang } \\
\text { untuk beralih pada bisnis bunga dan pala }\end{array}$ & & & & 4 & 3 & 12 \\
\hline & $\begin{array}{l}\text { Permintaan dari bahan mentah (ikan) yang tinggi dan } \\
\text { kebutuhan akan uang cash }\end{array}$ & & & & 4 & 3 & 12 \\
\hline & Masalah kontinuitas produksi karena tergantung musim & & & & 4 & 3 & 12 \\
\hline & $\begin{array}{l}\text { Ada program Pemerintah untuk difersivikasi olahan } \\
\text { misalnya sagu }\end{array}$ & 4 & 2 & 8 & & & \\
\hline \multirow{2}{*}{$\begin{array}{l}\text { Standard \& } \\
\text { Sertifikasi serta } \\
\text { pengendalian } \\
\text { mutu }\end{array}$} & $\begin{array}{l}\text { Kemudahan dalam mengurus standardisasi dan sertifikat } \\
\text { pada tahap produksi }\end{array}$ & 4 & 3 & 12 & & & \\
\hline & $\begin{array}{l}\text { Ada inisiasi pemerintah untuk membuat rumah produksi } \\
\text { dengan standard kualiatas tertentu }\end{array}$ & 4 & 1 & 4 & & & \\
\hline \multirow[t]{7}{*}{ Infrastruktur } & Kerusakan prasarana yang jalan raya & & & & 3 & 2 & 6 \\
\hline & $\begin{array}{l}\text { Kapasitas bandar udara untuk jenis pesawat yang memiliki } \\
\text { kapasitas besar }\end{array}$ & & & & 4 & 1 & 4 \\
\hline & Kerusakan prasarana yang listrik & & & & 4 & 2 & 8 \\
\hline & Gangguan koneksi internet & & & & 4 & 1 & 4 \\
\hline & Ganguan pada frekuensi radio/televisi & & & & 4 & 2 & 8 \\
\hline & $\begin{array}{l}\text { Ada alokasi anggaran tahunan untuk pemeliharaan } \\
\text { infrastuktur }\end{array}$ & & & & 3 & 3 & 9 \\
\hline & Kerusakan Jejaring telepon & & & & 4 & 2 & 8 \\
\hline \multirow[t]{2}{*}{ Pembiayaan } & Trust dari lembaga keuangan & & & & 4 & 2 & 8 \\
\hline & Total Skor & & & 24 & & & 122 \\
\hline
\end{tabular}

Sumber: Data Primer, 2019 


\section{Indikator Distribusi}

Distribusi merupakan salah satu indikator pada dimensi proses EKRAF kuliner. Indikator distribusi meliputi SDM, moda distribusi, distribusi produk, teknologi kemasan dan labeling, infrastruktur, pembiayaan dan jejaring. Pembobotan kekuatan dan kelemahan pada indikator distibusi menunjukkan bahwa infrastuktur, moda distribusi terutama darata dan laut memiliki skor yang tinggi dan menjadi kekuatan (skor 68). Sedangkan indikator lainnya memiliki skor yang rendah dan menjadi kelemahan (skor 28) pada indikator distribusi. Secara rinci besaran skor pada setiap indikator dapat dilihat pada Tabel 8.

Hasil pembobotan peluang dan ancaman pada indikator distribusi menunjukkan bahwa nilai skor peluang adalah nol dan ancaman sebesar 80 terutama pada indikator sumberdaya manusia, moda distribusi, dan infrastruktur (Tabel 9). Pemekaran wilayah menjadi ancaman bagi ketersediaan tenaga kerja pada kegiatan distribusi. Pada moda distribusi ancaman utama adalah pelayaran yang tidak regular karena cuaca selain kapasitas angkutan udara dan keterbatasan jumlah maskapai yang beroperasi di Kabupaten Fakfak. Ancaman utama pada infrastruktur adalah kerusakan jalan dan jembatan, pemadaman listrik karena kapasitas pembangkitnya, gangguan koneksi internet dan telepon. Pada pembiayaan, ancaman utama adalah rendahnya kepercayaan pemodal kepada pelaku bisnis.

\section{Indikator Konsumsi}

Indikator konsumsi terdiri dari konsumen, pengetahuan, utilitas, teknologi, infrastruktur, sarana, pembiayaan, jejaring, dan pemasaran. Hasil pembobotan kekuatan (skor 92) pada indikator konsumsi menunjukkan bahwa skor tersebar ada pada utilitas, teknologi, infrastruktu dan sarana. Kelemahan dengan skor 40 terutama berada pada indikator konsumen, pengetahuan dan pemasaran. Pada indikator konsumen, ditemukan bahwa pengetahuan tentang kebutuhan konsumen; evaluasi demand, segmentasi konsumen, perluasan demand dan peningkatan selera konsumen masih rendah. Demikian pula halnya pada indikator pengetahuan dimana belum tersedia referenssi sebagai sumber pengetahuan pada tahap konsumsi baik berupa buku, dokumen, berita dan film menjadi kelemahan. Indikator pemasaran dalam hal ini ketersediaan teknik pemasaran, ketersediaan riset dan pengembangan pasar, peta demand, kesesuaian produksi dengan daya dukung dan waktu pendistribusian menjadi kelamahan pada indikator konsumsi. Secara rinci hasil pembobotan kekuatan dan kelemahan dapat dilihat pada Tabel 10.

Tabel 8. Pembobotan Kekuatan dan Kelemahan pada Indikator Distribusi

\begin{tabular}{|c|c|c|c|c|c|c|c|}
\hline \multirow{2}{*}{$\begin{array}{l}\text { Indikator } \\
\text { Distribusi }\end{array}$} & \multirow{2}{*}{ Kriteria } & \multicolumn{3}{|c|}{ Kekuatan } & \multicolumn{3}{|c|}{ Kelemahan } \\
\hline & & Integrity & Rating & Skor & Integrity & Rating & Skor \\
\hline \multirow{4}{*}{$\begin{array}{l}\text { Sumbedaya } \\
\text { Manusia }\end{array}$} & Tersedia Jasa Kurir & & & & 4 & 1 & 4 \\
\hline & Tenaga Pengawas & & & & 4 & 0 & 0 \\
\hline & Manager & & & & 4 & 0 & 0 \\
\hline & Tenaga Ahli/Professional & & & & 4 & 0 & 0 \\
\hline \multirow{3}{*}{ Moda Distribusi } & Angkutan darat & 4 & 3 & 12 & & & \\
\hline & Angkutan laut & 4 & 2 & 8 & & & \\
\hline & Angkutan Udara & & & & 4 & 0 & 0 \\
\hline \multirow{3}{*}{ Distribusi Produk } & Kualitas produk terjaga & & & & 4 & 1 & 4 \\
\hline & Tepat waktu & & & & 4 & 0 & 0 \\
\hline & Minim Penolakan & & & & 4 & 0 & 0 \\
\hline \multirow{3}{*}{$\begin{array}{l}\text { Teknologi } \\
\text { Kemasan dan } \\
\text { Labelling }\end{array}$} & $\begin{array}{l}\text { Ketersediaan teknologi yang berguna untuk } \\
\text { mengidentifikasi produk }\end{array}$ & 4 & 1 & 4 & & & \\
\hline & $\begin{array}{l}\text { Ketersediaan teknologi yang berguna untuk } \\
\text { mengidentifikasi keterangan isi kandungan }\end{array}$ & & & & 4 & 1 & 4 \\
\hline & Ketersediaan teknologi yang berguna untuk alat promosi & & & & 4 & 1 & 4 \\
\hline \multirow{5}{*}{ Infrastruktur } & Jalan raya & 4 & 3 & 12 & & & \\
\hline & Jembatan & 4 & 3 & 12 & & & \\
\hline & Listrik & 4 & 2 & 8 & & & \\
\hline & Jejaring Telepon & 4 & 2 & 8 & & & \\
\hline & Jejaring Internet & 4 & 1 & 4 & & & \\
\hline Pembiayaan & Ketersediaan lembaga yang mendukung tahap distribusi & & & & 4 & 1 & 4 \\
\hline \multirow{3}{*}{ Jejaring Network } & $\begin{array}{l}\text { Ketersediaan jejaring untuk mendukung tahap distribusi di } \\
\text { tingkat lokal }\end{array}$ & & & & 4 & 1 & 4 \\
\hline & $\begin{array}{l}\text { Ketersediaan jejaring untuk mendukung tahap distribusi di } \\
\text { tingkat nasional }\end{array}$ & & & & 4 & 1 & 4 \\
\hline & $\begin{array}{l}\text { Ketersediaan jejaring untuk mendukung tahap distribusi di } \\
\text { tingkat internasional }\end{array}$ & & & & 4 & 0 & 0 \\
\hline \multicolumn{2}{|r|}{ Total } & & & 68 & & & 28 \\
\hline
\end{tabular}


Tabel 9. Pembobotan Peluang dan Ancaman Pada Indikator Distribusi

\begin{tabular}{|c|c|c|c|c|c|c|c|}
\hline \multirow{2}{*}{ Indikator Distribusi } & \multirow{2}{*}{ Kriteria } & \multicolumn{3}{|c|}{ Peluang } & \multicolumn{3}{|c|}{ Ancaman } \\
\hline & & Integrity & Rating & Skor & Integrity & Rating & Skor \\
\hline Sumbedaya Manusia & Pemekaran wilayah menyerap banyak tenaga kerja & & & & 4 & 3 & 12 \\
\hline \multirow{3}{*}{ Muda Distribusi } & Aspek cuaca yang menggangu pelayaran & & & & 4 & 2 & 8 \\
\hline & Jadwal pelayaran angkutan laut yang tidak reguler & & & & 4 & 2 & 8 \\
\hline & $\begin{array}{l}\text { Kapasitas Angkutan Udara dan jumlah maskapai } \\
\text { yang terbatas }\end{array}$ & & & & 4 & 0 & 0 \\
\hline \multirow{3}{*}{ Distribusi Produk } & Kualitas produk terjaga & & & & 4 & 1 & 4 \\
\hline & Tepat waktu & & & & 4 & 0 & 0 \\
\hline & Minim Penolakan & & & & 4 & 0 & 0 \\
\hline $\begin{array}{l}\text { Teknologi Kemasan } \\
\text { dan Labelling }\end{array}$ & $\begin{array}{l}\text { Teknologi kemasan dan labelling tidak dihasilkan } \\
\text { sendiri }\end{array}$ & & & & 4 & 0 & 0 \\
\hline \multirow{5}{*}{ Infrastruktur } & Kerusakan Jalan raya & & & & 4 & 2 & 8 \\
\hline & Kerusakan Jembatan & & & & 4 & 2 & 8 \\
\hline & Gangguan pemadaman Listrik & & & & 4 & 2 & 8 \\
\hline & Gangguan pada Jejaring Telepon & & & & 4 & 2 & 8 \\
\hline & Gangguan pada Jejaring Internet & & & & 4 & 2 & 8 \\
\hline Pembiayaan & Trust dari lembaga keuangan & & & & 4 & 2 & 8 \\
\hline \multicolumn{2}{|r|}{ Total Skor } & & & & & & 80 \\
\hline
\end{tabular}

Sumber: Data Primer, 2019

Tabel 10 Pembobotan Kekuatan dan Kelemahan pada Indikator Konsumsi

\begin{tabular}{|c|c|c|c|c|c|c|c|}
\hline \multirow[b]{2}{*}{ Indikator Konsumsi } & \multirow[b]{2}{*}{ Kriteria } & \multicolumn{3}{|c|}{ Kekuatan } & \multicolumn{3}{|c|}{ Kelemahan } \\
\hline & & Integrity & Rating & Skor & Integrity & $\begin{array}{c}\text { Ratin } \\
\text { g }\end{array}$ & Skor \\
\hline Konsumen & $\begin{array}{l}\text { Pengetahuan tentang kebutuhan konsumen (evaluasi } \\
\text { demand, segmentasi konsumen, perluasan demand, } \\
\text { peningktan selera konsumen) }\end{array}$ & & & & 4 & 1 & 4 \\
\hline \multirow[b]{2}{*}{ Pengetahuan } & $\begin{array}{l}\text { Tersedia sumber pengetahuan pada tahap konsumsi } \\
\text { (buku, referensi, dokument, berita, film dsb.) }\end{array}$ & & & & 4 & 1 & 4 \\
\hline & $\begin{array}{l}\text { Tersedia lembaga pendidikan yang menyediakan } \\
\text { sumber pengetahuan seperti perpustakaan, lembaga } \\
\text { pendidikan }\end{array}$ & & & & 4 & 1 & 4 \\
\hline Utilitas & $\begin{array}{l}\text { Keperluan memenuhi kebutuhan rumahtangga, } \\
\text { sekolah dan tempat kerja }\end{array}$ & 4 & 2 & 8 & & & \\
\hline \multirow{2}{*}{ Teknologi } & $\begin{array}{l}\text { Ketersediaan teknologi untuk mempermudah tahap } \\
\text { konsumsi }\end{array}$ & 4 & 3 & 12 & & & \\
\hline & $\begin{array}{l}\text { Teknologi informasi yang mempermudah tahap } \\
\text { konsumsi }\end{array}$ & 4 & 2 & 8 & & & \\
\hline \multirow{6}{*}{ Infrastruktur } & $\begin{array}{l}\text { Ketersediaan infrastruktur jalan yang mendukung } \\
\text { tahap konsumsi }\end{array}$ & 4 & 3 & 12 & & & \\
\hline & $\begin{array}{l}\text { Ketersediaan infrastruktur jembatan yang } \\
\text { mendukung tahap konsumsi }\end{array}$ & 4 & 2 & 8 & & & \\
\hline & $\begin{array}{l}\text { Ketersediaan infrastruktur listrik yang mendukung } \\
\text { tahap konsumsi }\end{array}$ & 4 & 2 & 8 & & & \\
\hline & $\begin{array}{l}\text { Ketersediaan infrastruktur internet yang mendukung } \\
\text { tahap konsumsi }\end{array}$ & & & & 4 & 1 & 4 \\
\hline & $\begin{array}{l}\text { Ketersediaan infrastruktur frekuensi radio/televisi } \\
\text { yang mendukung tahap konsumsi }\end{array}$ & 4 & 3 & 12 & & & \\
\hline & $\begin{array}{l}\text { Ketersediaan infrastruktur Jejaring telepon yang } \\
\text { mendukung tahap konsumsi }\end{array}$ & 4 & 2 & 8 & & & \\
\hline \multirow{2}{*}{ Sarana } & $\begin{array}{l}\text { Ketersediaan sarana/alat transportasi yang } \\
\text { mendukung tahap konsumsi }\end{array}$ & 4 & 2 & 8 & & & \\
\hline & $\begin{array}{l}\text { Ketersediaan sarana/aneka retail yang mendukung } \\
\text { tahap konsumsi }\end{array}$ & 4 & 2 & 8 & & & \\
\hline \multirow{2}{*}{ Pembiayaan } & $\begin{array}{l}\text { Ketersediaan lembaga keuangan perbankan yang } \\
\text { mendukung tahap konsumsi }\end{array}$ & & & & 4 & 0 & 0 \\
\hline & $\begin{array}{l}\text { Ketersediaan lembaga keuangan non - perbankan } \\
\text { yang mendukung tahap konsumsi }\end{array}$ & & & & 4 & 0 & 0 \\
\hline \multirow{3}{*}{ Jejaring/Network } & $\begin{array}{l}\text { Ketersediaan jejaring komunitas untuk mendukung } \\
\text { tahap konsumsi di tingkat lokal }\end{array}$ & & & & 4 & 0 & 0 \\
\hline & $\begin{array}{l}\text { Ketersediaan jejaring komunitas untuk mendukung } \\
\text { tahap konsumsi di tingkat nasional }\end{array}$ & & & & 4 & 0 & 0 \\
\hline & $\begin{array}{l}\text { Ketersediaan jejaring komunitas untuk mendukung } \\
\text { tahap konsumsi di tingkat internasional }\end{array}$ & & & & 4 & 0 & 0 \\
\hline \multirow{5}{*}{ Pemasaran } & Ketersediaan teknik pemasaran & & & & 4 & 1 & 4 \\
\hline & Ketersediaan riset dan pengembangan pasar & & & & 4 & 1 & 4 \\
\hline & Ketersediaan peta demand & & & & 4 & 1 & 4 \\
\hline & $\begin{array}{l}\text { Kesesuaian dengan produksi dan kapasitas daya } \\
\text { dukung }\end{array}$ & & & & 4 & 1 & 4 \\
\hline & Waktu pendistribusian & & & & 4 & 1 & 4 \\
\hline & Total & & & 92 & & & 36 \\
\hline
\end{tabular}

Sumber: Data Primer, 2019

Ancaman terbesar pada indikator konsumsi adalah pada infrastruktur dan pembiayaan. Kerusakan jalan dan jembatan juga gangguan pemadaman listrik, gangguan pada komunikasi telepon dan internet menjadi ancaman pada indikator konsumsi selain kepercayaan dari lembaga keuangan. Pembobotan indikator dapat dilihat pada Tabel 11.

Journal of Fiscal and Regional Economy Studies 
Tabel 11 Pembobotan Peluang dan Ancaman pada Indikator Konsumsi

\begin{tabular}{|c|c|c|c|c|c|c|c|}
\hline \multirow{2}{*}{ Indikator Konsumsi } & \multirow{2}{*}{ Kriteria } & \multicolumn{3}{|c|}{ Peluang } & \multicolumn{3}{|c|}{ Ancaman } \\
\hline & & Integrity & Rating & Skor & Integrity & Rating & Skor \\
\hline Sumbedaya Manusia & $\begin{array}{l}\text { Ada lembaga penelitian atau PT yang bisa membantu } \\
\text { untuk melakukan evaluasi terhadap demand, } \\
\text { perluasan demand, segmentasi konsumen, } \\
\text { peningkatan selera konsumen }\end{array}$ & 4 & 2 & 8 & & & \\
\hline Pengetahuan & $\begin{array}{l}\text { Internet dengan bergabai sumber bacaan yang dapat } \\
\text { diakses }\end{array}$ & 4 & 2 & 8 & & & \\
\hline Utilitas & Trend untuk hidup sehat dan mencintai budaya & 4 & 3 & 12 & & & \\
\hline \multirow{5}{*}{ Infrastruktur } & Kerusakan Jalan raya & & & & 4 & 2 & 8 \\
\hline & Kerusakan Jembatan & & & & 4 & 2 & 8 \\
\hline & Gangguan pemadaman Listrik & & & & 4 & 2 & 8 \\
\hline & Gangguan pada Jejaring Telepon & & & & 4 & 2 & 8 \\
\hline & Gangguan pada Jejaring Internet & & & & 4 & 2 & 8 \\
\hline Pembiayaan & Trust dari lembaga keuangan & & & & 4 & 1 & 4 \\
\hline \multicolumn{2}{|r|}{ Total Skor } & & & 28 & & & 44 \\
\hline
\end{tabular}

Sumber: Data Primer, 2019

\section{Dimensi Aktor}

Aktor di dalam pemeringkatan ekonomi kreatif di Kabupaten Fakfak meliputi pemerintah, komunitas, akademisi dan pelaku bisnis. Indikator pada masing-masing aktor berbeda sesuai perannya di dalam pengembangan EKRAF kuliner. Indikator-indikator yang dinilai pada aktor pemerintah meliputi penyedia suprastruktur, penyedia infrstruktur, kelembagaan, dan sinergi antara aktor. Sedangkan pada komunitas, indikator-indikator yang dinilai berupa rasio komunitas, umur komunitas, produk, afiliasi, kegiatan dan sibergi antar aktor. Indikator-indikator yang dinilai dari aktor akademisi antara lain: akademisi, perguruan tinggi dan sinergi antar aktor. Indikator-indikator aktor pelaku bisnis meliputi rasio pelaku bisnis, kontribusi ekonomi, rasio perusahaan bisnis kreatif dan sinergi antara aktor.

\section{Hasil Analisis SWOT Pada Dimensi Aktor Sektor EKRAF Kuliner}

Hasil pembobotan kekuatan dan kelemahan pada dimensi aktor EKRAF kuliner menunjukkan bahwa berdasarkan kriteria-kriteria penilaian skor kekuatan adalah sebesar 138 dibandingkan kelemaha sebera 126. Pada aktor pemerintah kriteria-kreteria yang memiliki skor besar adalah pada adanya kebijakan landasan untuk pengembangan EKRAF daerah, adanya program-program yang secara tidak langsung mendukung pengembangan EKRAF kuliner, secara kelembagaan sektor kuliner telah berpartisipasi pada festival, pameran dan promosi nasional, dan adanya koordinasi yang baik antar OPD. Pada aktor komunitas, kriteriakriteria berikut memiliki skor tinggi yakni usia komunitas kuliner telah cukup lama, adanya sinergi antara aktor dan rasio komunitas kuliner. Pada aktor akademisi, keberadaan politeknik Fakfak melalui penelitian-penelitian inovatif dan Universitas Papua melalui penelitian dan pengabdian serta sinergi antar aktor menjadi kekuatan sektor kuliner. Pada pelaku bisnis, kriteria dengan skor besar adalah pada kontribusi ekonomi dari sektor EKRAF kuliner bagi perekonomian daerah selain sinergi antara aktor. Secara rinci hasil pembobotan kekuatan dan kelemahan dari indikator aktor dapat dilihat pada Tabel 12 .

Pembobotan pada peluang dan ancaman pada indikator aktor menunjukkan bahwa peluang memiliki skor paling tinggi (158) dibandingkan ancaman (142). Kriteria-kriteria berupa kebijakan nasional terkait pembentukan BEKRAF daerah, EKRAF sebagai sektor unggulan, otonomi daerah dan sinergi antara Organisasi Perangkat Daerah (OPD) memiliki skor tertinggi pada aktor pemerintah. Walaupun terdapa kelemahan (dengan skor tinggi) pada indikator yang sama dari aktor pemerintah yakni perubahan kebijakan daerah dan tidak adanya perubahan political will dari kepala daerah yang berimplikasi pada tidak adanya alokasi dana dan perubahan anggaran menjadi ancaman. Kriteriakriteria lain pada aktor lainnya yang memiliki peluang dalam pengembangan EKRAF kuliner misalnya pada akademis; peningkatan kapasitas pengajar pada politeknik Fakfak menjadi peluang bagi pengembangan EKRAF kuliner selain perubahan ekonomi yang mendorong pelaku bisnis kreatif untuk berkreasi secara inovatif dalam mengembangkan usaha EKRAF kuliner. Secara rinci hasil pembobotan ancaman dan peluang pada indikator aktor dapat dilihat pada Tabel 13. 
Tabel 12 Pembobotan Kekuatan dan Kelemahan Pada Indikator Aktor

\begin{tabular}{|c|c|c|c|c|c|c|c|c|c|}
\hline \multirow[b]{2}{*}{ Aktor } & \multirow[b]{2}{*}{ Indikator } & \multicolumn{4}{|c|}{ Kekuatan } & \multicolumn{4}{|c|}{ Kelemahan } \\
\hline & & Kriteria & Integrity & Ratin & Skor & Kriteria & Integrity & Rating & Skor \\
\hline \multirow[t]{9}{*}{ Pemerintah } & \multirow[t]{3}{*}{$\begin{array}{l}\text { Penyedia } \\
\text { Suprastruktur }\end{array}$} & $\begin{array}{l}\text { Kebijakan landasan untuk } \\
\text { pengembangan EKRAF }\end{array}$ & 4 & 2 & 8 & $\begin{array}{l}\text { Alokasi dana untuk Pelaksaan } \\
\text { Kebijakan landasan untuk } \\
\text { pengembangan EKRAF }\end{array}$ & 4 & 1 & 4 \\
\hline & & $\begin{array}{l}\text { Renstra dengan penyataan } \\
\text { mendukung EKRAF }\end{array}$ & 4 & 1 & 4 & $\begin{array}{l}\text { Program-program pendukung EKRAF } \\
\text { kurang memberi perhatian pada } \\
\text { pemasaran dan strategi pemasaran }\end{array}$ & 4 & 1 & 4 \\
\hline & & $\begin{array}{l}\text { Program-program pendukung } \\
\text { EKRAF }\end{array}$ & 4 & 2 & 8 & $\begin{array}{l}\text { Penyusunan RESNTRA Daerah yang } \\
\text { mendukung EKRAF }\end{array}$ & 4 & 1 & 4 \\
\hline & \multirow[t]{4}{*}{$\begin{array}{l}\text { Penyedia } \\
\text { Infrastruktur }\end{array}$} & $\begin{array}{l}\text { Insiasi pembangunan rumah } \\
\text { produksi yang menjamin kualitas } \\
\text { produk }\end{array}$ & 4 & 1 & 4 & $\begin{array}{l}\text { Integrasi EKRAF dalam kontrak } \\
\text { politik calon Kepala Daerah dan atau } \\
\text { legislatif }\end{array}$ & 4 & 0 & $\mathbf{0}$ \\
\hline & & $\begin{array}{l}\text { Pergudangan, penampungan, dan } \\
\text { penyimpanan }\end{array}$ & 4 & 1 & 4 & $\begin{array}{l}\text { Rumah produksi yang menjamin } \\
\text { kualitas produk }\end{array}$ & 4 & 1 & 4 \\
\hline & & $\begin{array}{l}\text { Infrastruktur yang mendukung } \\
\text { Penanganan pascapanen }\end{array}$ & 4 & 1 & 4 & Pergudangan dan penyimpanan & 4 & 1 & 4 \\
\hline & & Infrastruktur Pemasaran & 4 & 1 & 4 & $\begin{array}{l}\text { Infrastruktur yang mendukung } \\
\text { Penanganan pascapanen }\end{array}$ & 4 & 1 & 4 \\
\hline & $\begin{array}{l}\text { Kelembagaa } \\
\mathrm{n}\end{array}$ & $\begin{array}{l}\text { Partisipasi dari sub-sektor kuliner } \\
\text { pada festival/pameran nasional } \\
\text { promosi }\end{array}$ & 4 & 2 & 8 & Infrastruktur Pemasaran & 4 & 1 & 4 \\
\hline & $\begin{array}{l}\text { Sinergi } \\
\text { antara aktor }\end{array}$ & $\begin{array}{l}\text { Hubungan koordinasi antara OPD } \\
\text { telah terjalin }\end{array}$ & 4 & 2 & 8 & $\begin{array}{l}\text { Aspek partisipasi dalam ajang } \\
\text { internasional }\end{array}$ & 4 & 1 & 4 \\
\hline \multirow[t]{6}{*}{ Komunitas } & $\begin{array}{l}\text { Rasio } \\
\text { komunitas }\end{array}$ & Pelaku bisnis EKRAF kuliner & 3 & 2 & 6 & $\begin{array}{l}\text { Apresiasi terhadap pelaku bisnis, hasil } \\
\text { karya dan wirausaha }\end{array}$ & 4 & 0 & $\mathbf{0}$ \\
\hline & $\begin{array}{l}\text { Umur } \\
\text { komunitas }\end{array}$ & $\begin{array}{l}\text { Usia komunitas pengusaha kuliner } \\
\text { lebih dari tiga tahun }\end{array}$ & 3 & 3 & 9 & $\begin{array}{l}\text { Pengembangan potensi EKRAF masih } \\
\text { sektoral dan tidak holistik }\end{array}$ & 4 & 1 & 4 \\
\hline & Produk & Difersivikasi produk & 4 & 1 & 4 & $\begin{array}{l}\text { Hubungan koordinasi antara OPD } \\
\text { telah terjalin tetapi hanya pada OPD } \\
\text { yang terkait dengan pengolahan hasil }\end{array}$ & 4 & 1 & 4 \\
\hline & Afiliasi & $\begin{array}{l}\text { Ada hubungan kekeluargaan antara } \\
\text { komunitas (bukan affiliasi bisnis) }\end{array}$ & 4 & 1 & 4 & $\begin{array}{l}\text { Pelaku bisnis EKRAF kuliner (dengan } \\
\text { penduduk) }\end{array}$ & 3 & 1 & 3 \\
\hline & Kegiatan & $\begin{array}{l}\text { Kegiatan oleh komunitas } \\
\text { berdasarkan cakupan }\end{array}$ & 4 & 1 & 4 & $\begin{array}{l}\text { Usia komunitas pengusaha kuliner } \\
\text { lebih dari tiga tahun }\end{array}$ & 3 & 3 & 9 \\
\hline & $\begin{array}{l}\text { Sinergi antar } \\
\text { aktor }\end{array}$ & $\begin{array}{l}\text { Kegiatan yang dilakukan bersama } \\
\text { oleh komunitas tertentu dengan } \\
\text { pemerintah, perusahaan, LSM } \\
\text { International }\end{array}$ & 4 & 2 & 8 & Difersivikasi produk & 4 & 2 & 8 \\
\hline \multirow[t]{4}{*}{ Akademisi } & Akademisi & $\begin{array}{l}\text { Pengajar di Politeknik dengan } \\
\text { kualifikasi tertentu yang } \\
\text { mendukung EKRAF }\end{array}$ & 3 & 1 & 3 & Affiliasi antara komunitas & 4 & 1 & 4 \\
\hline & \multirow[t]{2}{*}{$\begin{array}{l}\text { Perguruan } \\
\text { Tinggi }\end{array}$} & $\begin{array}{l}\text { Unipa mendukung berkembangnya } \\
\text { EKRAF melalui penelitian }\end{array}$ & 3 & 2 & 6 & $\begin{array}{l}\text { Jejaring antara komunitas sub-sektor } \\
\text { kuliner }\end{array}$ & 4 & 1 & 4 \\
\hline & & $\begin{array}{l}\text { Politeknik yang melakukan } \\
\text { penelitian2 inovatif }\end{array}$ & 4 & 2 & 8 & $\begin{array}{l}\text { Kegiatan (event) bersama antara } 2 \\
\text { atau lebih komunitas }\end{array}$ & 4 & 1 & 4 \\
\hline & $\begin{array}{l}\text { Sinergis } \\
\text { antar aktor }\end{array}$ & $\begin{array}{l}\text { Pemerintah berkejasama dengan } \\
\text { UNIPA, BP juga perbankan }\end{array}$ & 4 & 2 & 8 & $\begin{array}{l}\text { Kegiatan yang dilakukan bersama oleh } \\
\text { komunitas tertentu dengan pemerintah, } \\
\text { perusahaan, LSM International }\end{array}$ & 4 & 1 & 4 \\
\hline \multirow[t]{9}{*}{$\begin{array}{l}\text { Pelaku } \\
\text { Bisnis }\end{array}$} & $\begin{array}{l}\text { Rasio pelaku } \\
\text { bisnis }\end{array}$ & $\begin{array}{l}\text { Pelaku bisnis EKRAF (individu dan } \\
\text { kelopok terhadap pelaku bisnis) }\end{array}$ & 3 & 1 & 3 & $\begin{array}{l}\text { Pengajar di Politeknik dengan } \\
\text { kualifikasi tertentu yang mendukung } \\
\text { EKRAF }\end{array}$ & 4 & 2 & 8 \\
\hline & $\begin{array}{l}\text { Kontribusi } \\
\text { ekonomi }\end{array}$ & Nilai ekonomi kegiatan EKRAF & 3 & 3 & 9 & $\begin{array}{l}\text { Mendukung berkembangnya EKRAF } \\
\text { melalui penelitian }\end{array}$ & 4 & 1 & 4 \\
\hline & $\begin{array}{l}\text { Rasio } \\
\text { perusahaan } \\
\text { bisnis kreatif }\end{array}$ & $\begin{array}{l}\text { Unit bisnis EKRAF terhadap unit } \\
\text { bisnis }\end{array}$ & 3 & 2 & 6 & $\begin{array}{l}\text { Penelitian2 inovatif yang dilakukan } \\
\text { oleh politeknik Fakfak }\end{array}$ & 4 & 1 & 4 \\
\hline & \multirow{5}{*}{$\begin{array}{l}\text { Sinergi } \\
\text { antaraktor }\end{array}$} & \multirow{5}{*}{$\begin{array}{l}\text { Sinergi internal antara pelaku bisnis } \\
\text { dengan pemerintah }\end{array}$} & \multirow{5}{*}{4} & \multirow{5}{*}{2} & \multirow{5}{*}{8} & $\begin{array}{l}\text { Kerjasama anatara perguruan tinggi, } \\
\text { perusahaan, pemerintah, perbankan } \\
\text { dan LSM }\end{array}$ & 4 & 1 & 4 \\
\hline & & & & & & $\begin{array}{l}\text { Rasio pelaku bisnis EKRAF (individu } \\
\text { dan kelompok terhadap pelaku bisnis) }\end{array}$ & 4 & 2 & 8 \\
\hline & & & & & & Nilai ekonomi kegiatan EKRAF & 3 & 3 & 9 \\
\hline & & & & & & $\begin{array}{l}\text { Unit bisnis EKRAF terhadap unit } \\
\text { bisnis }\end{array}$ & 3 & 3 & 9 \\
\hline & & & & & & $\begin{array}{l}\text { Sinergi internal antara pelaku bisnis } \\
\text { dengan akademisi }\end{array}$ & 4 & 1 & 4 \\
\hline & & TOTAL & 85 & 38 & 138 & TOTAL & 104 & 34 & 126 \\
\hline
\end{tabular}

Sumber: Data Primer, 2019

\section{Skenario Pengembangan Sektor EKRAF Kuliner}

Berdasarkan pembobotan kriteria-kriteria pada komponen SWOT yakni kekuatan, kelemahan, peluang dan ancaman selanjutnya dilakukan penentuan kuadran untuk memperoleh skenarioskenario pengembangan sektor kuliner dengan formula sebagai berikut:

$(\mathrm{X}: \mathrm{Y})$

S-W/2:O-T/2

Dimana, S : Kekuatan

W: Kelemahan

\section{O: Peluang}

\section{T: Ancaman}

Penjumlahan skor dari dimensi sektor, proses dan aktor pada sektor EKRAF kuliner akan digunakan untuk memetakan kuadran dan skrenario pengembangan. Berdasarkan formula diatas maka penjumlahan skor pada setiap dimensi adalah sebagai berikut:

1) Dimensi sektor:

$\mathrm{S}-\mathrm{W} / 2: \mathrm{O}-\mathrm{T} / 2$

$156-36 / 2: 60-72 / 2$

Journal of Fiscal and Regional Economy Studies 
$\mathrm{X}=60$

$\mathrm{Y}=-6$

2) Dimensi proses:

$\mathrm{S}-\mathrm{W} / 2$ : O-T/2

276-272/2:136/278/2

$\mathrm{X}=2$
$\mathrm{Y}=-71$

3) Dimensi aktor:

$\mathrm{S}-\mathrm{W} / 2$ : O-T/2

$138-126 / 2: 158-142 / 2$

$\mathrm{X}=6$

$\mathrm{Y}=8$

Tabel 13 Pembobotan Ancaman dan Peluang Pada Indikator Aktor

\begin{tabular}{|c|c|c|c|c|c|c|c|c|c|}
\hline \multirow{2}{*}{ Aktor } & \multirow{2}{*}{ Indikator } & \multicolumn{4}{|l|}{ Ancaman } & \multicolumn{4}{|c|}{ Peluang } \\
\hline & & Kriteria & Integrity & Rating & Skor & Kriteria & Integrity & Rating & Skor \\
\hline \multirow{8}{*}{ Pemerintah } & \multirow{3}{*}{$\begin{array}{l}\text { Penyedia } \\
\text { Suprastruktur }\end{array}$} & Perubahan kebijakan daerah & 4 & 3 & 12 & $\begin{array}{l}\text { Kebijakan Nasional terkait } \\
\text { pembentuk BEKRAF Daerah }\end{array}$ & 4 & 3 & 12 \\
\hline & & \multirow[t]{2}{*}{$\begin{array}{l}\text { Tidak adanya/perubahan Political will } \\
\text { dari kepala daerah terkait EKRAF }\end{array}$} & \multirow[t]{2}{*}{4} & \multirow[t]{2}{*}{3} & \multirow[t]{2}{*}{12} & $\begin{array}{l}\text { Sektor unggulan saat ini adalah } \\
\text { pengembangan ekonomi kreatif }\end{array}$ & 4 & 3 & 12 \\
\hline & & & & & & $\begin{array}{l}\text { Otonomi daerah untuk mengatur } \\
\text { perekonomian daerah }\end{array}$ & 4 & 3 & 12 \\
\hline & \multirow[t]{2}{*}{$\begin{array}{l}\text { Penyedia } \\
\text { Infrastruktur }\end{array}$} & $\begin{array}{l}\text { Alokasi dana untuk penyediaan } \\
\text { infrasturktur terhambat }\end{array}$ & 4 & 3 & 12 & $\begin{array}{l}\text { Rumah produksi yang menjamin } \\
\text { kualitas produk belum } \\
\text { direalisasikan (sedang dalam } \\
\text { proses negosiasi dengan } \\
\text { pemerintah daerah) } \\
\end{array}$ & 4 & 1 & 4 \\
\hline & & $\begin{array}{l}\text { Perubahan anggaran yang memengaruhi } \\
\text { pembangunan infrastruktur }\end{array}$ & 4 & 3 & 12 & $\begin{array}{l}\text { Diberi kesempatan berpartisipasi } \\
\text { pada pameran atau lomba kuliner } \\
\text { di tingkat nasional }\end{array}$ & 4 & 2 & 8 \\
\hline & & $\begin{array}{l}\text { Keterbatasan informasi terkait festival } \\
\text { atau acara internasional }\end{array}$ & 4 & 1 & 4 & $\begin{array}{l}\text { Partisipasi pada festival dan acara } \\
\text { internasional }\end{array}$ & 4 & 2 & 8 \\
\hline & Kelembagaan & $\begin{array}{l}\text { Keterbatasan dana untuk berpartisipasi } \\
\text { pada festival dan acara internasional }\end{array}$ & 3 & 1 & 3 & $\begin{array}{l}\text { Hubungan kerjasama dan } \\
\text { koordinasi internal antara OPD } \\
\text { telah terjalin tetapi hanya pada } \\
\text { OPD yang terkait dengan } \\
\text { pengolahan hasil }\end{array}$ & 4 & 3 & 12 \\
\hline & $\begin{array}{l}\text { Sinergi } \\
\text { antara aktor }\end{array}$ & $\begin{array}{l}\text { Hubungan kerjasama dan koordinasi } \\
\text { internal terkait hal-hal yang mendukung } \\
\text { pengembangan EKRAF }\end{array}$ & 4 & 2 & 8 & $\begin{array}{l}\text { Pelaku bisnis EKRAF kuliner } \\
\text { (dengan penduduk) }\end{array}$ & 3 & 2 & 6 \\
\hline \multirow{6}{*}{ Komunitas } & $\begin{array}{l}\begin{array}{l}\text { Rasio } \\
\text { komunitas }\end{array} \\
\end{array}$ & Berkurangnya pengusaha EKRAF & 3 & 2 & 6 & $\begin{array}{l}\text { Usia komunitas pengusaha } \\
\text { kuliner lebih dari tiga tahun }\end{array}$ & 3 & 3 & 9 \\
\hline & $\begin{array}{l}\text { Umur } \\
\text { komunitas }\end{array}$ & $\begin{array}{l}\text { Usia komunitas pengusaha kuliner lebih } \\
\text { dari tiga tahun }\end{array}$ & 3 & 3 & 9 & $\begin{array}{l}\text { Permintaan konsumen untuk } \\
\text { Difersivikasi produk atau harga }\end{array}$ & 4 & 2 & 8 \\
\hline & Produk & Perubahan perilaku konsumen & 4 & 2 & 8 & Affiliasi antara komunitas & 3 & 1 & 3 \\
\hline & Afiliasi & Trust antara komunitas & 4 & 1 & 4 & $\begin{array}{l}\text { Jejaring antara komunitas sub- } \\
\text { sektor kuliner }\end{array}$ & 3 & 2 & 6 \\
\hline & Kegiatan & $\begin{array}{l}\text { Waktu dan dana untuk melakukan } \\
\text { kegiatan bersama }\end{array}$ & 3 & 1 & 3 & $\begin{array}{l}\text { Kegiatan (event) bersama antara } \\
2 \text { atau lebih komunitas }\end{array}$ & 3 & 1 & 3 \\
\hline & $\begin{array}{l}\text { Sinergi antar } \\
\text { aktor }\end{array}$ & $\begin{array}{l}\text { Waktu dan anggaran untuk melakukan } \\
\text { kerjasama dengan aktor lainnya }\end{array}$ & 3 & 1 & 3 & $\begin{array}{l}\text { Kegiatan yang dilakukan bersama } \\
\text { oleh komunitas tertentu dengan } \\
\text { pemerintah, perusahaan, LSM } \\
\text { International }\end{array}$ & 3 & 1 & 3 \\
\hline \multirow{4}{*}{ Akademisi } & Akademisi & $\begin{array}{l}\text { Jumlah pengajar di Politeknik dengan } \\
\text { kualifikasi tertentu yang mendukung } \\
\text { EKRAF }\end{array}$ & 4 & 2 & 8 & $\begin{array}{l}\text { Pengajar di Politeknik dengan } \\
\text { kualifikasi tertentu yang } \\
\text { mendukung EKRAF }\end{array}$ & 4 & 2 & 8 \\
\hline & \multirow{2}{*}{$\begin{array}{l}\text { Perguruan } \\
\text { Tinggi }\end{array}$} & $\begin{array}{l}\text { Dana dan waktu untuk kegiatan } \\
\text { pengabdian dan penelitian oleh } \\
\text { perguruan tinggi yang mendukung } \\
\text { EKRAF }\end{array}$ & 3 & 1 & 3 & $\begin{array}{l}\text { Kegiatan pengabdian dan } \\
\text { penelitian oleh perguruan tinggi } \\
\text { yang mendukung EKRAF }\end{array}$ & 3 & 2 & 6 \\
\hline & & $\begin{array}{l}\text { Funding tidak tersedia untuk kegaitan } \\
\text { penelitian inovatif yang dilakukan oleh } \\
\text { politeknik Fakfak }\end{array}$ & 3 & 2 & 6 & $\begin{array}{l}\text { Penelitian2 inovatif yang } \\
\text { dilakukan oleh politeknik Fakfak }\end{array}$ & 3 & 2 & 6 \\
\hline & $\begin{array}{l}\text { Sinergis } \\
\text { antar aktor }\end{array}$ & $\begin{array}{l}\text { Tidak ada kerjasama antara perguruan } \\
\text { tinggi, perusahaan, pemerintah, } \\
\text { perbankan dan LSM }\end{array}$ & 3 & 1 & 3 & $\begin{array}{l}\text { Kerjasama antara perguruan } \\
\text { tinggi, perusahaan, pemerintah, } \\
\text { perbankan dan LSM }\end{array}$ & 3 & 2 & 6 \\
\hline \multirow{6}{*}{$\begin{array}{l}\text { Pelaku } \\
\text { Bisnis }\end{array}$} & $\begin{array}{l}\text { Rasio pelaku } \\
\text { bisnis }\end{array}$ & $\begin{array}{l}\text { Pertumbuhan penduduk dan mobilisasi } \\
\text { penduduk }\end{array}$ & 3 & 2 & 6 & $\begin{array}{l}\text { Pertumbuhan penduduk dan } \\
\text { mobilisasi penduduk }\end{array}$ & 3 & 2 & 6 \\
\hline & \multirow[t]{2}{*}{$\begin{array}{l}\text { Kontribusi } \\
\text { ekonomi }\end{array}$} & $\begin{array}{l}\text { Pertumbuhan ekonomi nasional yang } \\
\text { melambat mendorong orang untuk } \\
\text { meningkatkan kreativitas dalam } \\
\text { wirausaha }\end{array}$ & 3 & 1 & 3 & $\begin{array}{l}\text { Pertumbuhan ekonomi nasional } \\
\text { yang melambat mendorong orang } \\
\text { untuk meningkatkan kreativitas } \\
\text { dalam wirausaha }\end{array}$ & 3 & 2 & 6 \\
\hline & & Pembukaan lapangan kerja baru & 3 & 1 & 3 & Perubahan perilaku konsumen & 4 & 2 & 8 \\
\hline & $\begin{array}{l}\text { Rasio } \\
\text { perusahaan } \\
\text { bisnis kreatif }\end{array}$ & $\begin{array}{l}\text { Situasi yang tidak kondusif untuk } \\
\text { pengembangan bisnis kreatif }\end{array}$ & 4 & 2 & 8 & $\begin{array}{l}\text { Sinergi internal antara pelaku } \\
\text { bisnis dengan akademisi }\end{array}$ & 3 & 2 & 6 \\
\hline & $\begin{array}{l}\text { Sinergi } \\
\text { antaraktor }\end{array}$ & $\begin{array}{l}\text { Waktu dan anggaran untuk melakukan } \\
\text { kerjasama dengan aktor lainnya }\end{array}$ & 3 & 2 & 6 & & & & \\
\hline & \multicolumn{2}{|r|}{ TOTAL } & 76 & 40 & 142 & TOTAL & 76 & 45 & 158 \\
\hline
\end{tabular}

\section{Sumber: Data Primer, 2019}

Hasil perhitungan nilai $\mathrm{X}$ dan $\mathrm{Y}$ kemudian digunakan untuk menentukan skenario-skenario pengembangan EKRAF kuliner di Kabupaten
Fakfak. Secara rinci hasil analisis SWOT pada sektor kuliner dapat dilihat pada pada Gambar 2. 


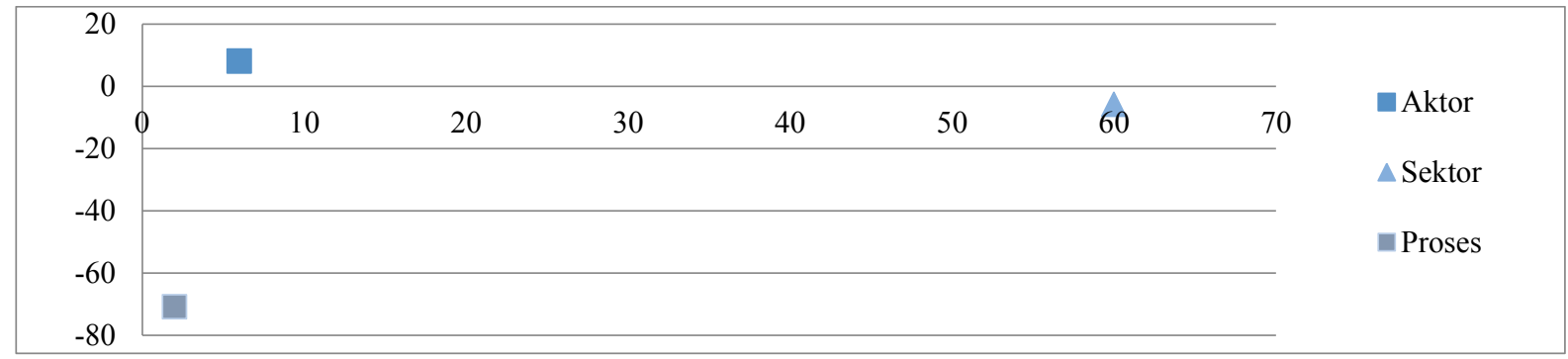

Sumber : Data Primer, 2018

\section{Gambar 2. Hasil Analisis SWOT Pada Sektor Kuliner}

Analisis SWOT menunjukkan bahwa sektor kuliner berada pada kuadran I dan II. Secara rinci dimensi aktor kuliner berada pada kaudran I. Artinya aktor kuliner memiliki peluang dan kekuatan sehingga kebijakan yang diambil adalah memanfaatkan peluang untuk meningkatkan produksi. Strategi-strategi pada kuadran I dan kuadran II yakni peningkatan produksi yang lebih agresif atau diversifikasi produk harus didukung oleh peralatan dan teknologi yang memadai. Teknologi tepat guna dibutuhkan untuk meningkatkan produksi dan mengurangi beban kerja yang besar bagi pelaku bisnis kuliner yang sebagian besar perempuan. Dimensi sektor dan proses kuliner berada pada kuadran II. Artinya, walaupun sektor ini menghadapi berbagai ancaman dari segi internal terutama pada dimensi proses dan dimensi sektor, kuliner masih memiliki kekuatan yakni pada dimensi aktor. Ancaman pada sektor kuliner terutama karena dimensi sektor ini sebagian besar menggunakan bahan baku dari produk pertanian dan perikanan yang sangat dipergaruhi oleh karakteristik produk pertanian, musim dan iklim. Upaya besar perlu dilakukan untuk meningkatkan performa sektor EKRAF kuliner terutama pada dimensi proses. Berdasarkan hasil analisis SWOT, ancaman terbesar pada dimensi proses adalah berada pada indikator kreasi produksi, distribusi dan konsumsi. Pada indikator kreasi terdapat beberapa aspek pendukung yang urgensinya (integrity) cukup tinggi tetapi pemenuhannya (rating) untuk saat ini (ketika penelitian ini dilakukan) masih sangat rendah. Aspek-aspek pendukung tersebut adalah sumberdaya manusia, pengetahuan, teknologi, ketrampilan, pembiayaan dan jejaring. Pada indikator kreasi sumberdaya manusia terdapat dua hal yang seharusnya menjadi perhatian dalam pengembangan sektor kuliner EKRAF di Kabupaten Fakfak. Keterbatasan sumberdaya manusia sebagai kreator kuliner terutama lulusan sekolah vokasi yang jumlahnya masih sedikit banyak terserap sebagai pegawai negeri untuk memenuhi kebutuhan ketenagakerjaan pada pemerintahan di wilayah-wilayah pemekaran baru. Terbatasnya jumlah lulusan dari sekolahsekolah vokasi yang menciptakan kreator-kreator kuliner disebabkan oleh masih sedikitnya sekolah-sekolah vokasi tersebut.

Hasil analisis SWOT ini kemudian dilanjutkan dengan melakukan penggabungan berbagai indikator dengan menggunakan TOWS matriks. Berdasarkan hasil penggabungan indikatorindikator tersebut maka pada sektor kuliner ada dua skenario yang dapat dilakukan dengan strategi-strategi tertentu yakni skenario pada kuadran I dan skenarion pada kuadran II. Secara rinci strategi-strategi pada kuadran I dan kuadran II dijelaskan pada Tabel 14. Berdasarkan hasil analisis dengan menggunakan TOWS matriks, strategi pengembangan ekonomi kreatif berada pada kuadran I (strategi SO) dan kuadran II (strategi ST). Strategi SO pada kuadran I yakni menggunakan kekuatan untuk merebut peluang adalah sebagai berikut:

a) Menciptakan teknologi dan perlatan tepat guna yang mendukung proses produksi;

b) Difersifikasi jenis produk yang dihasilkan;

c) Melakukan perluasan pasar dengan menjual keunggulan-keunggulan produk dan daerah;

d) Diversifikasi strategi pemasaran dengan menggunakan media online;

e) Penelitian-penelitian tentang evaluasi terhadap demand, perluasan demand, segmentasi konsumen, dan peningkatan selera konsumen;

f) Pelatihan kepada pelaku bisnis diarahkan pada peningkatan kapasitas untuk memahami pasar dan strategi pemasaran;

g) Memperkuat infrastruktur pendukung pemasaran seperti koneksi internet;

h) Memperkuat infrastruktur pendukung energi untuk kegiatan produksi. 
Strategi ST pada kuadran II adalah sebagai berikut:

a) Mengembangkan sekolah-sekolah vokasi yang mendukung EKRAF kuliner;

b) Program edukasi untuk mengembangkan jiwa kewirausahaan (entrepreneurship) pada generasi muda; c) Pelatihan pengelolaan keuangan dan organisasi, perencanaan bisnis diberikan kepada pelaku-pelaku bisnis;

d) Mengembangkan strategi atau lembaga yang menyediakan cadangan dana bagi pelaku bisnis dengan berbagai kemudahan yang dapat membantu mereka.

\section{Tabel 14. Strategi Pengembangan Sektor Kuliner Berdasarkan Matriks TOWS}

\begin{tabular}{|c|c|c|}
\hline Ekstenal & $\begin{array}{l}\text { Kekuatan (Strengths) } \\
\text { - Bahan baku yang digunakan diperoleh dengan } \\
\text { cara budidaya organik } \\
\text { - Bahan baku tersedia secara lokal } \\
\text { - Sumbedaya manusia yang menciptakan kreasi } \\
\text { kuliner } \\
\text { - Ada sumber dana yang digunakan untuk } \\
\text { pembiayaan kegiatan industri ini } \\
\text { - Ada pasar ditingkat lokal } \\
\text { - Prasrana jalan tersedia } \\
\text { - Usaha kuliner telah cukup lama (lebih dari tiga } \\
\text { tahun) dilakukan } \\
\text { - Jumlah pelaku bisnis banyak } \\
\text { - Memberikan kontribusi ekonomi yang cukup } \\
\text { tinggi } \\
\text { - Terdapat balai penelitian pertanian } \\
\text { - Insiasi pembangunan rumah produksi yang } \\
\text { menjamin kualitas produk } \\
\text { - Politeknik yang menghasilkan penelitian- } \\
\text { penelitian inovatif } \\
\text { - Sinergi antara pemerintah, Universitas (UNIPA), } \\
\text { BP Tangguh juga perbankan }\end{array}$ & $\begin{array}{l}\text { Kelemahan (Weaknesses) } \\
\text { - Sebagian besar usaha kuliner adalah } \\
\text { non-formal } \\
\text { - Lembaga pendidikan yang mencetak } \\
\text { aktor yang bekerja pada sektor kuliner } \\
\text { tidak ada } \\
\text { - Jenis produk yang dihasilkan hanya } \\
\text { berupa Appetizer dan dissert (belum ke } \\
\text { main course) } \\
\text { - Ketersediaan bahan baku tidak regular } \\
\text { (musiman) } \\
\text { - Perlatan yang digunakan pada tahap } \\
\text { proses masih sederhana } \\
\text { - Standard dan sertifikat penjaminan mutu } \\
\text { baru pada produk-produk olahan } \\
\text { tertentu } \\
\text { - Penyimpanan dan pergudangan tidak } \\
\text { ada } \\
\text { - Belum ada perlindungan pada tenaga } \\
\text { kerja di sektor kuliner } \\
\text { - Sebagian besar dilakukan oleh } \\
\text { perempuan yang juga memiliki beban } \\
\text { kerja rumahtangga dan aktivitas sosial } \\
\text { yang tinggi }\end{array}$ \\
\hline $\begin{array}{l}\text { Peluang (Oppurtunity) } \\
\text { - Ada program-program pelatihan bagi } \\
\text { pelaku bisnis kuliner } \\
\text { - Selera konsumen dan gaya hidup sehat } \\
\text { (healthy life trend) } \\
\text { - Ada bantuan modal usaha dari } \\
\text { perusahaan dan lembaga keuangan } \\
\text { perbankan } \\
\text { - Pemasaran secara online menjadi trend } \\
\text { saat ini } \\
\text { - Pala sebagai ole-ole khas Fakfak } \\
\text { - Ada kebijakan pangan lokal } \\
\text { - EKRAF menjadi sektor unggulan saat } \\
\text { ini } \\
\text { - Ada lembaga penelitian atau PT yang } \\
\text { bisa membantu untuk melakukan } \\
\text { evaluasi terhadap demand, perluasan } \\
\text { demand, segmentasi konsumen, } \\
\text { peningkatan selera konsumen }\end{array}$ & $\begin{array}{l}\text { SO Strategy (Kuadran I) } \\
\text { - Menciptakan teknologi \& perlatan tepat guna } \\
\text { yang mendukung proses produksi } \\
\text { - Difersifikasi jenis produk yang dihasilkan } \\
\text { - Melakukan perluasan pasar dengan menjual } \\
\text { keunggulan-keunggulan produk dan daerah } \\
\text { - Diversifikasi strategi pemasaran dengan } \\
\text { menggunakan media online } \\
\text { - Penelitian-penelitian tentang evaluasi terhadap } \\
\text { demand, perluasan demand, segmentasi } \\
\text { konsumen, peningkatan selera konsumen } \\
\text { - Pelatihan kepada pelaku bisnis untuk peningkatan } \\
\text { kapasitas terkait memahami pasar dan strategi } \\
\text { pemasaran } \\
\text { - Memperkuat infrastruktur pendukung pemasaran } \\
\text { seperti koneksi internet } \\
\text { - Memperkuat infrastruktur pendukung energi } \\
\text { untuk kegiatan produksi }\end{array}$ & WO Strategy (Kuadran VI) \\
\hline $\begin{array}{l}\text { Ancaman (Threats) } \\
\text { - Topografi dan jarak yang jauh sulit } \\
\text { untuk pengangkutan bahan baku } \\
\text { - Pemekaran wilayah mendorong orang } \\
\text { untuk beralih menjadi PNS } \\
\text { - Gangguan lingkungan terhadap produksi } \\
\text { bahan baku } \\
\text { - Harga bunga pala (fuli) dan biji yang } \\
\text { tinggi mendorong orang untuk beralih } \\
\text { pada bisnis primer (bunga pala (fuli) dan } \\
\text { pala) } \\
\text { - Permintaan dari bahan mentah (ikan) } \\
\text { yang tinggi untuk eksport } \\
\text { - Trust dari pemberi modal } \\
\text { - Keterbatasan informasi terkait festival } \\
\text { atau acara internasional } \\
\text { - Gangguan koneksi internet } \\
\text { - Gangguan kerusakan infrastuktur }\end{array}$ & $\begin{array}{l}\text { ST Strategy (Kuadran II) } \\
\text { - Mengembangkan sekolah-sekolah vokasi yang } \\
\text { mendukung EKRAF kuliner } \\
\text { - Program edukasi untuk mengembangkan jiwa } \\
\text { kewirausahaan (entrepreneurship) pada generasi } \\
\text { muda } \\
\text { - Pelatihan pengelolaan keuangan dan organisasi, } \\
\text { perencanaan bisnis diberikan kepada pelaku- } \\
\text { pelaku bisnis } \\
\text { - Mengembangkan strategi atau lembaga yang } \\
\text { menyediakan cadangan dana bagi pengusaha } \\
\text { dengan berbagai kemudahan yang dapat } \\
\text { membantu mereka }\end{array}$ & WT Strategy (III) \\
\hline
\end{tabular}

Sumber: Data Primer, 2018 


\section{KESIMPULAN}

Dalam pertumbuhan perekonomian yang melambat ini, pengembangan potensi ekonomi kreatif daerah di Kabupaten Fakfak perlu dilakukan. Pengembangan ekonomi kreatif akan menjaga keberlanjutan ekonomi daerah. Berdasarkan hasil pembobotan potensi ekonomi kreatif daerah, terdapat lima sektor potensial di Kabupaten Fakfak dari 16 sektor EKRAF. Kelima sektor ini memiliki bobot yang tinggi. Hasil Analisis Hirarki Proses (AHP) menyimpulkan bahwa sektor dengan bobot tertinggi adalah kuliner dengan bobot antara $0.164-0,178$. Dimensi-dimensi yang digunakan sebagai indikator dalam penilaian potensi EKRAF adalah dimensi sub-sektor, dimensi aktor dan dimensi proses dengan masing-masing elemen. Pada dimensi sub-sektor sumberdaya manusia dan ketersediaan bahan baku menjadi point tertinggi dalam pengembangan potensi ekonomi kreatif di kabupaten Fakfak. Sedangkan pada dimensi aktor, pemerintah yang memiliki peran yang besar dalam mendukung, membina dan memberikan infrastruktur pada sektor-sektor ekonomi kreatif. Penilian AHP menunjukkan bahwa peran aktor pemerintah memiliki nilai tertinggi pada sektor kuliner.

Sektor EKRAF kuliner memiliki kekuatan, kelemahan secara internal tetapi juga memiliki peluang dan ancaman dari sisi eksternal. Kekuatan, kelemahan, peluang dan ancaman pada setiap dimensi berbeda-beda. Secara umum sebagian besar usaha memiliki kekuatan tersebsar yakni ketersediaan bahan baku secara memadai dan berkelanjutan baik kuantitas maupun kualitas terutama secara organik. Kekuatan dari elemen kelembagaan adalah adanya kebijakan nasional tentang EKRAF. Walaupun belum ada regulasi tentang EKRAF daerah di Kabupaten Fakfak karena EKRAF masih relatif baru, Kabupaten Fakfak telah menginisiasi pengembangan EKRAF daerah dengan melakukan pemetaan potensi EKRAF sebagai pra-syarat pengembangan EKRAF. Beberapa bahan baku terutama sektor kuliner berasal dari sektor pertanian dan atau diambil dari alam tanpa melakukan tindakan budidaya. Oleh sebab itu memperkuat proses produksi dengan memperbaiki beberapa aspek seperti teknologi dan infrastruktur pada proses kreasi sambil menjajaki peluang-peluang seperti perluasan pasar. Kelemahan pada elemen bahan baku adalah dipengaruhi oleh musim dan ancaman karena karakteristik produk pertanian.
Dimensi proses pada kreasi dan distribusi pada kelima sektor EKRAF ini masih lemah. Sinergitas antara sektor-sektor EKRAF ini masih lemah. Aspek penting lainnya yang berkontribusi terhadap pengembangan EKRAF adalah permodalan. Sebagian besar modal yang digunakan untuk melakukan berbagai bisnis kreatif ini merupakan modal sendiri, bantuan dari lembaga perbankan (beberapa pelaku bisnis) dan lembaga non-perbankan.

Beberapa strategi yang dapat dilakukan untuk mendukung pengembangan EKRAF daerah berdasarkan analisis SWOT pada sektor-sektor potensial secara umum adalah memanfaatkan peluang-peluang yang ada untuk meningkatkan produksi secara agresif dan melakukan diferensiasi produk dan pasar. Strategi ini terutama dapat dilakukan pada sektor kuliner. Sektor kuliner pada dasarnya dapar disinergiskan dengan sektor potensial lainnya seperti sektor pariwisata. Difersifikasi produk pada sektor pariwisata mencakup paket-paket wisata yang bervariasi yakni paket wisata kuliner misalnya.

\section{UCAPAN TERIMAKASIH}

Penelitian ini didanai melalui kegiatan swakelola BAPPEDA Kabupaten Fakfak. Terimakasih kepada BAPPEDA Kabupaten Fakfak yang telah menyediakan dana penelitian ini. Juga terimakasih diberikan kepada Pemerintah Daerah Fakfak yang telah memfasilitasi kegiatan penelitian ini. Akhirnya ucapan terimakasih juga diberikan kepada masyarakat Fakfak yang terlibat di dalam penelitian ini.

\section{DAFTAR PUSTAKA}

Badan Ekonomi Kreatif Nasional. (2016). Sistem Ekonomi Kreatif Nasional: Panduan Pemeringkatan Kabupaten/Kota Kreatif.

Badan Pusat Statistik. (2016). Profil Ekonomi/Perusahaan 16 sub-sektor EKRAF Berdasarkan Sensus Ekonomi 2016. Badan Pusat Statistik

BPS Kabupaten Fakfak. (2017). Kabupaten Fakfak dalam Angka. Fakfak, Papua Barat: BPS Kabupaten Fakfak

Fajar Kurniawan. (20 Februari 2017). SWOT Analisis: Marketing feasibility study. Youtube. Diunduh dari https://youtu.be/ OErZjn2g3Qw

ILO-PCdP2 UNDP. (2013). Laporan Pemetaan Lembaga Keuangan Mikro dan Kajian 
Situasi Terkini Usaha Mikro di Kabupaten Manokwari dan Fakfak Provinsi Papua Barat. Program Pengembangan Berbasis Masyarakat Fase II

Khavidhurrohmaningrum. (2013). Strategi dan Perilaku Industri Pengolahan di Kota Semarang Tahun 2017-2011

Mulyana \& Sutapa. (2015). Peran Quadruple Helix dalam meningkatkan kreativitas dan kapabilitas inovasi (Studi pada industry kreatif sektor fashion). In $2^{\text {nd }}$ Conference in Business, Accounting and Management (pp.222-232)

Rangkuti, F. (2012). SWOT Balanced Skorcard. Teknik Menyusun Strategi Korporasi yang Efektif plus Cara Mengelola Kinerja dan Risiko. Ed.ke-3. Jakarta: PT. Gramedia Pustaka Utama

Saaty, Thomas, L. (1993). Pengambilan Keputusan Bagi Para Pemimpin. Proses Hirarki Analitik untuk Pengambil Keputusan dalam Situasi yang Kompleks. Jakarta: Pustaka Binaman Presindo

(2016). A Framework for Making Better Decision: How to Make More Effective Site Selection, Store Closing and Other Real Estate Decision. Research Review. 13(1) pp. 1-4
Saksono, H. ( 2012). Ekonomi Kreatif: Talenta Baru Pemicu Daya saing daerah. Pusat Penelitian dan Pengembangan Pemerintahan Umum dan Kependudukan Badan Penelitian dan Pengembangan (BPP) Kementerian Dalam Negeri. Jurnal Bina Praja. Vol 4.No.2 Juni 2012: 93-104.

Setyanto, A. \& Irawan, B. (2012). Pengembangan Kawasan Sentra Produksi Pertanian. Bagian Ketiga Metode Penentuan Komoditas Unggulan dan Wilayah Sentra Pengembangan. Pusat Sosial Ekonomi dan Kebijakan Pertanian. Biro Perencanaan Sekretaris Jendral Kementerian Pertanian

Suparmoko, M. (2002). Ekonomi Publik, untuk Keuangan dan Pengembangan Daerah. Jogjakarta: Andi

Suryana. (2013). Ekonomi Kreatif, Ekonomi Baru: Mengubah Ide dan Menciptakan Peluang. Jakarta: Salemba Empat

Sidauruk, R. (2013). Peningkatan Peran Pemerintah Daerah Dalam Rangka Pengembangan Ekonomi Kreatif di Provinsi Jawa Barat. Jurnal Bina Praja, Vol 5(3), pp. 141-158.

Patel. (2018). https://www.entrepreneur.com/ article/279786 diunduh pada tanggal 2 November 2018. 